Article

\title{
Improving Soil Nitrogen Availability and Rice Growth Performance on a Tropical Acid Soil via Mixture of Rice Husk and Rice Straw Biochars
}

\author{
Gunavathy Selvarajh (D), Huck Ywih Ch'ng*(D), Norhafizah Md Zain, Palsan Sannasi (D) and \\ Siti Nuurul Huda Mohammad Azmin (D)
}

check for

updates

Citation: Selvarajh, G.; Ch'ng, H.Y.;

Md Zain, N.; Sannasi, P.; Mohammad

Azmin, S.N.H. Improving Soil

Nitrogen Availability and Rice Growth Performance on a Tropical Acid Soil via Mixture of Rice Husk and Rice Straw Biochars. Appl. Sci. 2021, 11, 108. https://dx.doi.org/ 10.3390/app11010108

Received: 1 December 2020

Accepted: 22 December 2020

Published: 24 December 2020

Publisher's Note: MDPI stays neutral with regard to jurisdictional claims in published maps and institutional affiliations.

Copyright: (C) 2020 by the authors. Licensee MDPI, Basel, Switzerland. This article is an open access article distributed under the terms and conditions of the Creative Commons Attribution (CC BY) license (https: / / creativecommons.org/ licenses/by/4.0/).
Faculty of Agro-Based Industry, Campus Jeli, University Malaysia Kelantan, Kelantan 17600, Malaysia; gunavathy92@gmail.com (G.S.); norhafizah.mz@umk.edu.my (N.M.Z.); palsan.abdullah@umk.edu.my (P.S.); huda.ma@umk.edu.my (S.N.H.M.A.)

* Correspondence: huckywih@umk.edu.my; Tel.: +60-17-853-7510

Featured Application: This research focuses on using an environmentally friendly technology (mixture of rice straw and rice husk biochars) to sustainably minimize ammonia volatilization, increase soil nutrient retention, and improve rice plant nutrient uptake and use efficiency. The mixture of rice straw and rice husk biochars has a larger surface area and numerous pores to chelate ammonium and nitrate ions. This process will fundamentally reduce the loss of ammonia via volatilization from urea fertilizer being applied, thus reducing the excessive use of urea fertilizer in agricultural sector. The biochar at 5 and $10 \mathrm{tha}^{-1}$ significantly minimized ammonia volatilization by $33.5-40.7 \%$. It resulted in an increase of nutrient uptake, use efficiency, and dry matter production of rice plant. This work may not only contribute to the reduction of urea fertilizer import bill of Malaysia, but also pave the way for better means of adding value to the agricultural waste to avoid environmental pollution. It also contributes to increasing rice production by solving the problem of ammonia loss from urea fertilizer in tropical acid soil.

Abstract: Nitrogen deficiency frequently occurs at agricultural soil because of $\mathrm{NH}_{3}$ volatilization to the environment which results in low urea-N use efficiency by rice plants. A pot experiment was conducted to assess the synergistic effects of a mixture of rice straw and rice husk biochars (RSRH) on (1) total $\mathrm{N}$, soil exchangeable $\mathrm{NH}_{4}{ }^{+}$, and available $\mathrm{NO}_{3}{ }^{-}$, and (2) uptake of $\mathrm{N}, \mathrm{P}$, and $\mathrm{K}$ in rice plant. RSRH biochar at 5 and $10 \mathrm{t} \mathrm{ha}^{-1}$ had significantly minimized ammonia volatilization by $33.5 \%$ and $40.7 \%$. Further, RSRH biochars also had significantly increased available $\mathrm{NH}_{4}{ }^{+}, \mathrm{NO}_{3}{ }^{-}$, available $\mathrm{P}$, and available $\mathrm{K}$ in the soil over T1. In line to increase in soil nutrient availability, the rice plant height, tiller number, greenness, and panicle number were increased. This resulted in an increase of nutrient uptake, use efficiency, and dry matter production of the rice plant. RSRH biochar altered the soil environment by minimizing $\mathrm{NH}_{3}$ loss and increasing soil nutrients for efficient plant uptake.

Keywords: ammonia volatilization; biochar; nutrient uptake; urea

\section{Introduction}

Asian countries grow rice (Oryza sativa L.) in a huge acreage, where the production and consumption is the highest. Rice is cultivated in different diverse ecosystems, and irrigated lowland rice is the most important rice ecosystem in Malaysia [1]. Rice production in Malaysia is the highest at the irrigated lowland rice system because it is more economical and reliable. Although rice growers prefer irrigated lowland system for rice production, there are many arising problems in rice fields, such as increased fertilizer application rate due to volatilization or leaching of nitrogen $(\mathrm{N})$, which leads to poor rice crop growth $[2,3]$. Plants need $\mathrm{N}$ the most during the vegetative stage for proper growth and cell division, but the volatilization of $\mathrm{N}$ from applied urea fertilizer reduces the availability of $\mathrm{N}$ in 
the soil. To overcome the deficiency of $\mathrm{N}$ in the soil, rice growers tend to add excessive and unreasonable amounts of inorganic fertilizer, which adversely affect the quality of the environment [4]. These practices do not only waste the fertilizer and degrade nature, but are also costly. Major $\mathrm{N}$ loss from applied urea in irrigated lowland rice systems is due to the adoption of the surface applied method [5]. Due to surface application, immediately upon contact with water, urea hydrolyses and is lost through ammonia $\left(\mathrm{NH}_{3}\right)$ volatilization [6]. It also agreed that a main pathway of applied $\mathrm{N}$ loss in cropping systems is through $\mathrm{NH}_{3}$ volatilization [7]. The urea- $\mathrm{N}$ volatilization process needs to be minimized in the agricultural field in order to increase the rice plant $\mathrm{N}$ uptake and yield.

Agricultural waste can be used since it is cost effective, renewable, and abundant [8]. Rice residues such as rice straw and rice husk are one of the agricultural wastes that can be found in abundance and are being burnt to avoid excessive accumulation. One promising management approach is to convert the agricultural wastes into biochar. Recently, there has been much renewed interest in using biochar in the agricultural field as a soil ameliorant [9]. Turning rice residues to biochar can reduce the wastage problem and environmental pollution.

Biochar as an organic amendment offers a wide variety of benefits to the soil environment. It is a carbon-rich product obtained from wood, paper, manure, or wheat straw burned in a pyrolyzed condition [10]. Yeboah et al. [11] stated that biochar enhances soil nutrient retention, which overall reduces the total fertilizer requirements in agricultural soil. Further, a study by Yang et al. [12] concluded that biochar has a large surface area and numerous pores which aids in ions' adsorption capacity. These properties of biochar might increase the retention of ammonium $\left(\mathrm{NH}_{4}{ }^{+}\right)$and nitrate $\left(\mathrm{NO}_{3}{ }^{-}\right)$in soil [13]. Retention of $\mathrm{NH}_{4}{ }^{+}$and nitrate $\mathrm{NO}_{3}{ }^{-}$in soil is crucial for plant uptake and utilization. Further, biochar has a higher cation exchange capacity (CEC) value which further aids in more nutrient retention and increases its potential to be an adsorptive agent [14]. Biochar application reduces $\mathrm{NH}_{3}$ volatilization successfully and retains more nutrients in soil.

Previously, rice husk biochar had been used for $C$ sequestration and to minimize greenhouse gas emission in rice fields [15]. Rice fields are known as a major source of atmospheric greenhouse emission. Mohammadi et al. [16] stated that rice straw and rice husk conversion into biochar and its application reduced methane gas emission in the rice cultivation area. Much research has been conducted in rice fields by using biochar for $C$ sequestration and climate mitigation, but there is little research on soil amendments. Hence, there is a need to know the efficacy of rice straw and rice husk biochar on soil quality improvements. There is also a scarcity of information and research in amending rice straw and rice husk biochars with the soil to minimize $\mathrm{NH}_{3}$ loss in the agricultural field. The interaction between rice straw, rice husk biochar, and urea fertilizer applied in a soil cultivated with rice plant needs detailed research in order to integrate biochar in soil properly to achieve a sustainable management of rice fields. Thus, the objectives of this study were to: (i) Improve soil total $\mathrm{N}$, soil exchangeable $\mathrm{NH}_{4}{ }^{+}$, and soil available nitrate $\left(\mathrm{NO}_{3}{ }^{-}\right)$by using biochars produced from rice straw and rice husk, respectively, and (ii) determine whether the use of biochars improves $\mathrm{N}, \mathrm{P}, \mathrm{K}, \mathrm{Ca}$, and $\mathrm{Mg}$ uptake, nutrient use efficiency, and dry matter production of rice plant.

\section{Materials and Methods}

\subsection{Soil Sampling and Characterization}

The soil used in this study was sampled at 0-30 cm from an uncultivated land in Agro Techno Park of University Malaysia Kelantan Jeli Campus, Malaysia (5.6955 latitude and 101.8389 longitude) which has not been cultivated since 2007. The soils were collected randomly from a sampling area of $60 \times 60 \mathrm{~m}$. The collected soil samples were air-dried, crushed, and sieved to pass through a 2-mm sieve for initial soil characterization. Soil $\mathrm{pH}$ was measured in a ratio of 1:10 (soil:water) by using a digital $\mathrm{pH}$ meter [17]. Soil organic matter, ash content, and soil total carbon were determined by using the loss-on ignition method [18]. The total $\mathrm{N}$ was determined by using the Kjeldahl method [19]. 
The double acid method described by Mehlich [20] was used to extract soil available P and exchangeable cations $(\mathrm{Ca}, \mathrm{Mg}, \mathrm{K}$, and $\mathrm{Na}$ ), after which the cations were determined by using an atomic absorption spectrophotometer (AAS) (Analyst 800, Perkin Elmer, Norwalk, CT, USA), while soil available $\mathrm{P}$ was determined by using the molybdenum blue method of Murphy and Riley [21]. The developed blue color was analyzed by a UV-VIS spectrometer (Thermo Fisher Scientific Genesys 20, Waltham, MA, USA) at $882 \mathrm{~nm}$ wavelengths. Soil CEC was determined with the ammonium acetate leaching method [22]. The exchangeable acidity and exchangeable $\mathrm{Al}^{3+}$ were determined by the acid-base titration method described by Rowell [23]. The method described by Keeney and Nelson [24] was used to extract exchangeable $\mathrm{NH}_{4}{ }^{+}$and available $\mathrm{NO}_{3}{ }^{-}$, after which the ions were determined via steam distillation [18].

\subsection{Characterization of Rice Husk and Rice Straw}

Rice straw collected from the Kemubu granary area, Kota Bharu, Malaysia, and rice husk collected from Pasir Puteh Rice Mill, Malaysia were subjected to analysis of $\mathrm{pH}$ [17] and total $\mathrm{N}$ [19]. The single dry ashing method [18] was used to extract nutrients from rice husk and rice straw for analysis of $\mathrm{Ca}, \mathrm{Mg}, \mathrm{Na}, \mathrm{P}$, and $\mathrm{K}$. The contents of $\mathrm{Ca}, \mathrm{Mg}, \mathrm{Na}$, and $\mathrm{K}$ were determined by using an AAS (Analyst 800, Perkin Elmer, Norwalk, CT, USA). Meanwhile, total P content was determined by using the molybdenum blue method after which the blue color developed was analyzed using a UV-VIS spectrophotometer (Thermo Scientific Genesys 20, Waltham, MA, USA) [21]. Organic matter, ash content, exchangeable $\mathrm{NH}_{4}{ }^{+}$, available $\mathrm{NO}_{3}{ }^{-}$, and CEC were determined by using the aforementioned methods in the soil characterization section.

\subsection{Rice Husk and Rice Straw Biochar's Production and Activation}

Two cylindrical kilns, 200 L, with removable chimney caps and an air-tight 110-L drum, were constructed for biochar production. Rice straw and rice husk were bulked separately inside the 110-L drum and closed before being placed in the middle of the 200-L drum, where the fire was kindled starting from the bottom of the drum. The burning time was 4-6 h, with temperature ranging from 300-400 ${ }^{\circ} \mathrm{C}$ and left for cooling for $12 \mathrm{~h}$. After that, the pile of biochar samples was spread out for cooling. Next, activation of biochar was carried out by soaking the biochar with $5 \%$ chicken slurry for 7 days, which later was dried and stored in a big container for further use. Activation of biochar with chicken slurry is crucial to further increase the nutrient content, alter the surface area, and increase the pore size [25]. The analysis conducted for biochar characterization is similar to those of aforementioned characterizations of soil and rice straw. Additionally, microanalysis through scanning electron microscopy attached with energy dispersive X-ray spectroscopy analysis (SEM-EDX JEOL JSM 6400) was carried out to analyze the surface morphology of rice husk and rice straw biochars.

\subsection{Ammonia Loss Incubation Study}

The $\mathrm{NH}_{3}$ loss incubation study was conducted by using a close-dynamic air flow system [26-28]. The system came with an exchange chamber of a 250-mL conical flask containing the soil mixture and a 250-mL conical flask containing $75 \mathrm{~mL}$ of boric acid, which were both stoppered and fit with inlet/outlet pipes. The inlet of the chamber containing water was connected to an air pump and the outlet was connected by pipe tubing to the trap containing boric acid solution. This setup was done to create soil aeration and trap $\mathrm{NH}_{3}$ loss via the volatilization process.

Soil and the rice straw + rice husk biochar mixture (RSRH) at rates of 5, 10, 15, and $20 \mathrm{t} \mathrm{ha}^{-1}$ were mixed well before being deposited into the $250-\mathrm{mL}$ conical flask followed by the addition of $175 \mathrm{~kg} \mathrm{ha}^{-1}$ of urea. The produced biochars were compared with a commercial biochar potting media to compare the efficacy in reducing $\mathrm{NH}_{3}$ loss. For commercial biochar potting media mixture, $50 \%$ soil was mixed well with $50 \%$ commercial biochar potting media, and in another treatment $100 \%$ commercial biochar potting media 
was used. Later, urea was added into the commercial biochar potting media mixture. Next, water was added to create a waterlogged condition. The water level was marked in a conical flask and maintained $3 \mathrm{~cm}$ above the soil throughout the incubation study period. The boric acid solution was replaced every $24 \mathrm{~h}$ and back-titrated with $0.01 \mathrm{M} \mathrm{HCl}$ to determine $\mathrm{NH}_{3}$ loss from the applied urea. The measurement was continued until the $\mathrm{NH}_{3}$ decreased to $1 \%$ of the added $\mathrm{N}$ to the system [29]. After the ammonia volatilization study period, the soil samples were taken and the $\mathrm{pH}$, exchangeable $\mathrm{NH}_{4}{ }^{+}$, and available $\mathrm{NO}_{3}{ }^{-}$ were determined. Treatments were arranged in a completely randomized design (CRD) with three replications, as shown in Table 1.

Table 1. Treatments evaluated in ammonia volatilization study.

\begin{tabular}{cl}
\hline Treatment & \multicolumn{1}{c}{ Description } \\
\hline T0 & 100 g soil only (negative control) \\
T1 & $100 \mathrm{~g}$ soil $+0.97 \mathrm{~g}$ urea (positive control) \\
T2 & $100 \mathrm{~g}$ soil $+0.97 \mathrm{~g}$ urea $+0.14 \mathrm{~g}$ rice straw biochar $+0.14 \mathrm{~g}$ rice husk biochar \\
T3 & $100 \mathrm{~g}$ soil $+0.97 \mathrm{~g}$ urea $+0.28 \mathrm{~g}$ rice straw biochar $+0.28 \mathrm{~g}$ rice husk biochar \\
T4 & $100 \mathrm{~g}$ soil $+0.97 \mathrm{~g}$ urea $+0.42 \mathrm{~g}$ rice straw biochar $+0.42 \mathrm{~g}$ rice husk biochar \\
T5 & $100 \mathrm{~g}$ soil $+0.97 \mathrm{~g}$ urea $+0.56 \mathrm{~g}$ rice straw biochar $+0.56 \mathrm{~g}$ rice husk biochar \\
T6 & $50 \mathrm{~g}$ soil +50 g commercial biochar potting media $+0.97 \mathrm{~g}$ urea \\
T7 & 100 g of commercial biochar potting media $+0.97 \mathrm{~g}$ urea \\
\hline
\end{tabular}

\subsection{Pot Experiment}

After the completion of the laboratory $\mathrm{NH}_{3}$ loss incubation study, a pot experiment was conducted in a netted house located at the University Malaysia Kelantan Jeli Campus, Malaysia. Only 5 treatments were selected and carried forward to the pot experiment from the ammonia volatilization study. Treatments with 15 and $20 \mathrm{tha}^{-1}$ RSRH biochar were excluded. Application of 15 and $20 \mathrm{t} \mathrm{ha}^{-1}$ did not minimize $\mathrm{NH}_{3}$ loss significantly compared to 5 and $10 \mathrm{tha}^{-1}$ RSRH biochars. Hence, low rates of RSRH biochar application (5 and $10 \mathrm{t} \mathrm{ha}^{-1}$ ) were chosen since they were more economical. Treatments with soil only, soil + urea, and 50\% and 100\% commercial potting media were carried forward to the pot experiment to serve as a comparison to RSRH biochar effectiveness in minimizing $\mathrm{NH}_{3}$ loss and nutrient retention in soil, and improving plant nutrient uptake.

Rice plant (cultivar MR297) was used as a test crop in the pot experiment and the seedlings were planted in pots ( 23 height, 23 wide, and $23 \mathrm{~cm}$ diameter) which were filled with $5 \mathrm{~kg}$ of 5-mm sieved soil. Before planting, MR297 rice seeds were germinated in plastic trays filled with germination medium. The biochar rates of 5 and $10 \mathrm{t} \mathrm{ha}^{-1}$ were mixed thoroughly with the soil $24 \mathrm{~h}$ before transplantation of rice seedlings into the pot on the seventh day. Three rice seedlings were planted in each pot, equivalent to three seedlings per hill [30]. The water level in each pot was maintained at $3 \mathrm{~cm}$ from the soil surface. After seven days of transplantation, N, P, and K fertilizers in the form of urea $(46 \% \mathrm{~N})$, Christmas Island Rock phosphate $\left(32 \% \mathrm{P}_{2} \mathrm{O}_{5}\right)$, and Muriate of Potash $\left(60 \% \mathrm{~K}_{2} \mathrm{O}\right)$ were applied at rates of $175,97.8$, and $130 \mathrm{~kg} \mathrm{ha}^{-1}$, respectively. These rates were scaled down based on the recommendation of Muda Agricultural Development Authority, Malaysia [31] with some modifications where the urea was increased to 175 from $151 \mathrm{~kg} \mathrm{ha}^{-1}$ for $5 \mathrm{~kg}$ soil per pot. The fertilizers were applied in a three-equal split at 7, 30, and 55 days after transplantation (DAT) by surface application. The lists of treatments evaluated in the pot experiment are listed in Table 2.

The pot experiment was carried out in a completely randomized design with three replications in a net house. Plants were checked regularly and monitored up to the heading stage (70 days). The plants were harvested at 70 DAT. This is because the amount of soil used in the pot was not sufficient to support rice plants up to the flowering and ripening stage; thus, it was not economically practical to estimate the yield of rice based on pot experiments. This was in agreement with Palanivell et al. [32]. 
Table 2. Treatments evaluated in pot study.

\begin{tabular}{|c|c|}
\hline Treatment & Description \\
\hline T0 & $5 \mathrm{~kg}$ soil (negative control) \\
\hline $\mathrm{T} 1$ & $5 \mathrm{~kg}$ soil $+3.96 \mathrm{~kg}$ urea, $2.21 \mathrm{~kg} \mathrm{ha}^{-1} \mathrm{CIRP}$, and $2.94 \mathrm{~kg} \mathrm{ha}^{-1} \mathrm{MOP}$ (positive control) \\
\hline $\mathrm{T} 2$ & $\begin{array}{l}5 \mathrm{~kg} \text { soil }+3.96 \mathrm{~kg} \text { urea, } 2.21 \mathrm{~kg} \mathrm{ha}^{-1} \mathrm{CIRP} \text {, and } 2.94 \mathrm{~kg} \mathrm{ha}^{-1} \mathrm{MOP}+0.06 \mathrm{~kg} \text { rice } \\
\text { straw biochar }+0.06 \mathrm{~kg} \text { rice husk }\end{array}$ \\
\hline T3 & $\begin{array}{l}5 \mathrm{~kg} \text { soil }+3.96 \mathrm{~kg} \text { urea, } 2.21 \mathrm{~kg} \mathrm{ha}^{-1} \mathrm{CIRP} \text {, and } 2.94 \mathrm{~kg} \mathrm{ha}^{-1} \mathrm{MOP}+0.12 \mathrm{~kg} \text { rice } \\
\text { straw biochar }+0.12 \mathrm{~kg} \text { rice husk }\end{array}$ \\
\hline $\mathrm{T} 4$ & $\begin{array}{l}2.5 \mathrm{~kg} \text { soil }+2.5 \mathrm{~kg} \text { commercial biochar potting media }+3.96 \mathrm{~kg} \text { urea, } 2.21 \mathrm{~kg} \mathrm{ha}^{-1} \\
\text { CIRP, and } 2.94 \mathrm{~kg} \mathrm{ha}^{-1} \text { MOP }(50 \% \text { soil }+50 \% \text { commercial biochar potting media) }\end{array}$ \\
\hline T5 & $\begin{array}{l}5 \mathrm{~kg} \text { commercial biochar potting media }+3.96 \mathrm{~kg} \text { urea, } 2.21 \mathrm{~kg} \mathrm{ha}^{-1} \mathrm{CIRP} \text {, and } 2.94 \\
\mathrm{~kg} \mathrm{ha}^{-1} \mathrm{MOP}(100 \% \text { commercial biochar potting media })\end{array}$ \\
\hline
\end{tabular}

At the heading stage (70 DAT), the plant height was measured by using a measuring tape. Plant greenness was measured by using the SPAD Meter 502-nm. The number of tillers and number of panicles were counted and recorded. The aboveground parts of the plants were harvested and dried in an oven at $60{ }^{\circ} \mathrm{C}$ until a constant weight was attained [33]. The oven-dried plant samples were then grounded by using a grinding machine, after which they were analyzed for total N, P, and K. Total N was determined by using the Kjeldahl method. Meanwhile, the single dry ashing method was used to extract the total $\mathrm{P}$ and $\mathrm{K}$ in the plant tissues. The filtrates were analyzed by using AAS to determine the total $\mathrm{K}$, and total $\mathrm{P}$ was determined by using the molybdenum blue colorimetric method. The concentrations of N, P, and K in the leaf were multiplied by the dry weight of leaves to obtain the amount of N, P, and $\mathrm{K}$ uptake by the rice plants. Rice plant nutrient use efficiency was calculated using the method of Dobermann [34].

$$
\begin{aligned}
\text { Nutrient uptake } & =\text { Nutrient concentration }(\%) \times \text { plant dry weight }(\mathrm{g}) \\
& \text { Nutrient use efficiency }=\frac{A-B}{R} \times 100
\end{aligned}
$$

where $A=$ plant nutrient uptake from fertilized soil, $B=$ plant nutrient uptake from unfertilized soil, and $R=$ rate of fertilizer nutrients applied.

The soil samples from pots were collected immediately upon plant harvesting. The soil was air-dried, crushed, and sieved to pass through a 2-mm sieve. Afterwards, the soil samples were analyzed for $\mathrm{pH}$, Electrical conductivity (EC), total N, available $\mathrm{P}$, total organic matter, total $\mathrm{C}$, exchangeable acidity and $\mathrm{Al}$, and exchangeable cations $(\mathrm{K}, \mathrm{Ca}, \mathrm{Mg}$, $\mathrm{Zn}$, and $\mathrm{Fe}$ ) by using the aforementioned procedures in Section 2.1 (Soil Sampling and Characterization).

\subsection{Statistical Analysis}

Statistical analysis for all the data was performed by using SPSS software version 24.0 (SPSS Inc, Chicago, IL, USA). The effect of different rates of RSRH biochar addition on all the treatments was subjected to one-way analysis of variance (ANOVA). Significant differences among treatments were separated by Tukey's test and considered significant at $p \leq 0.05$.

\section{Results}

\subsection{Characteristics of Soil, Rice Straw, and Rice Husk Biochar}

Selected soil physico-chemical properties are profiled in Table 3. The soil was a sandy clay loam and acidic, with a $\mathrm{pH}$ of 5.5. The exchangeable acidity, $\mathrm{Al}$, and Fe were higher in the soil. The readily available soil total $\mathrm{N}, \mathrm{NH}_{4}{ }^{+}$, and $\mathrm{NO}_{3}{ }^{-}$were found to be generally low. Similarly, the available $\mathrm{P}, \mathrm{K}, \mathrm{Ca}, \mathrm{Mg}$, and $\mathrm{Na}$ were also low in the soil. 
Table 3. Selected soil physico-chemical properties.

\begin{tabular}{|c|c|}
\hline Property & Value Obtained \\
\hline $\mathrm{pH}$ & 5.5 \\
\hline $\mathrm{EC}\left(\mathrm{dS} \mathrm{m}^{-1}\right)$ & 0.022 \\
\hline Texture & Sandy Clay Loam \\
\hline Soil organic matter $(\%)$ & 6.24 \\
\hline Total organic matter $(\%)$ & 3.62 \\
\hline Ash content $(\%)$ & 6.4 \\
\hline Cation exchange capacity $\left(\mathrm{cmol}_{\mathrm{C}} \mathrm{kg}^{-1}\right)$ & 5.4 \\
\hline Ammonium (ppm) & 89 \\
\hline Nitrate (ppm) & 30 \\
\hline Total N (\%) & 0.07 \\
\hline Available P (ppm) & 0.385 \\
\hline Total C (\%) & 4.5 \\
\hline Available $\mathrm{K}\left(\mathrm{cmol}_{\mathrm{C}} \mathrm{kg}^{-1}\right)$ & 0.084 \\
\hline Available Ca $\left(\mathrm{cmol}_{\mathrm{c}} \mathrm{kg}^{-1}\right)$ & 0.10 \\
\hline Available $\mathrm{Mg}\left(\mathrm{cmol}_{\mathrm{C}} \mathrm{kg}^{-1}\right)$ & 0.082 \\
\hline Available $\mathrm{Na}\left(\mathrm{cmol}_{\mathrm{C}} \mathrm{kg}^{-1}\right)$ & 0.024 \\
\hline Available $\mathrm{Fe}\left(\mathrm{cmol}_{\mathrm{C}} \mathrm{kg}^{-1}\right)$ & 0.091 \\
\hline Exchangeable acidity $\left(\mathrm{cmol}_{\mathrm{C}} \mathrm{kg}^{-1}\right)$ & 0.7 \\
\hline Exchangeable $\mathrm{Al}\left(\mathrm{cmol}_{\mathrm{C}} \mathrm{kg}^{-1}\right)$ & 1.14 \\
\hline
\end{tabular}

RSRH biochars which were observed under a scanning electron microscope showed that biochar has a larger surface area and comes with numerous pores (Figures 1 and 2). Both biochars had a $(\mathrm{pH}>9)$ with a higher CEC value (Table 4$)$. The available $\mathrm{P}(14.3 \%)$ was very high in the RSRH biochar. The available cations K of RSRH biochar were considerably higher, at 12,030 and $4925 \mathrm{mg} \mathrm{kg}^{-1}$, respectively.

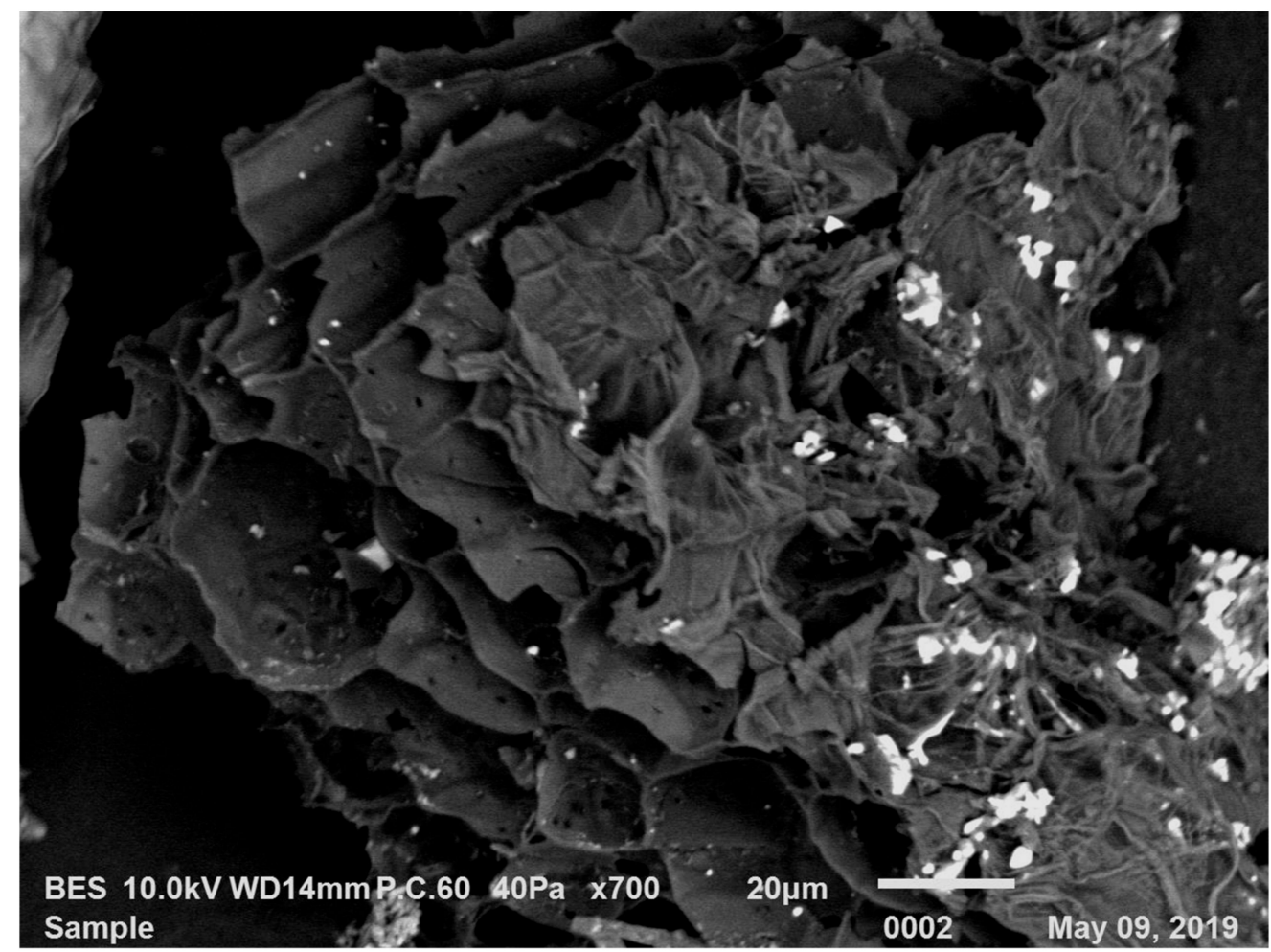

Figure 1. Rice husk biochar surface at 700× magnification under SEM. 


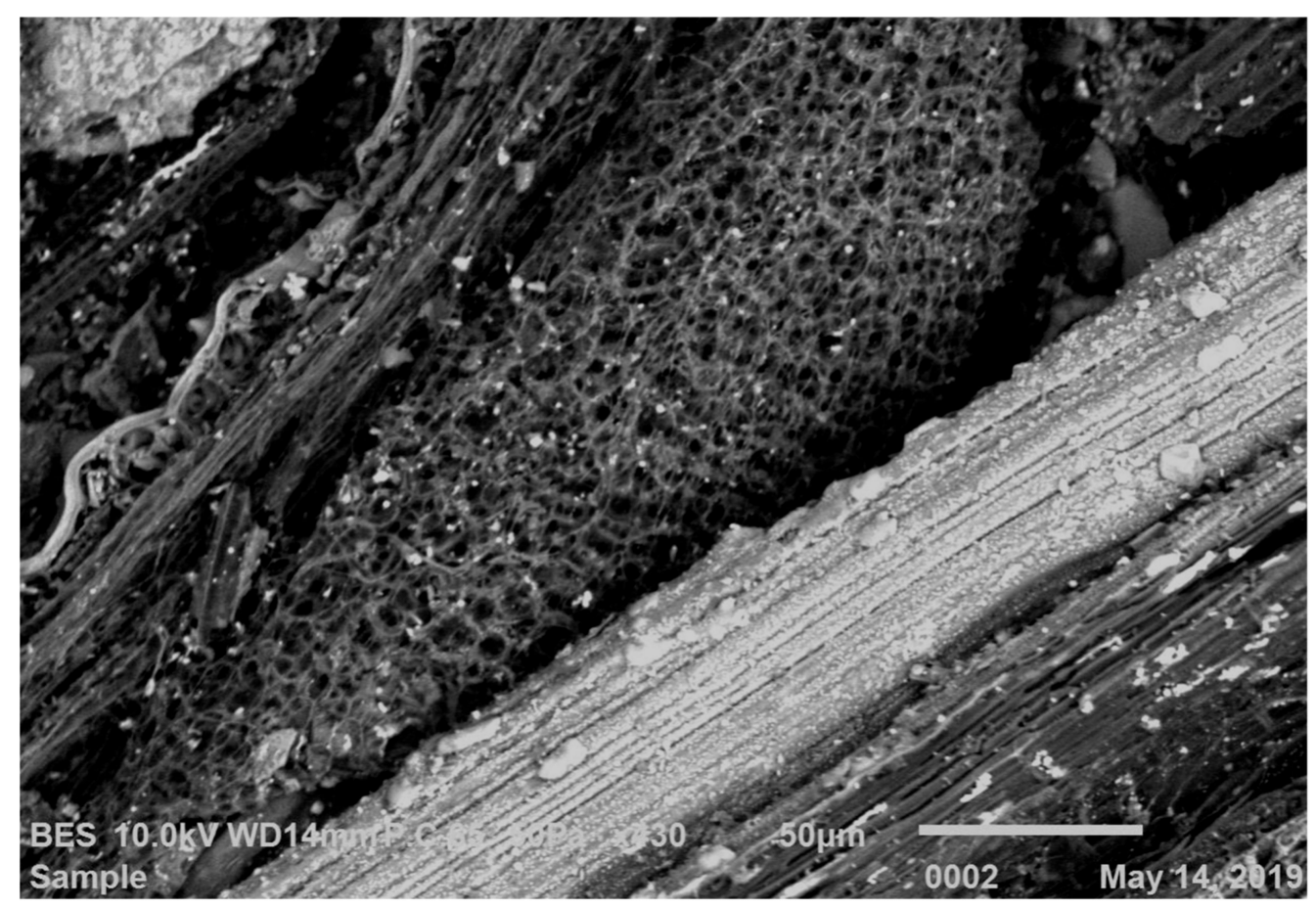

Figure 2. Rice straw biochar surface at $1000 \times$ magnification under SEM.

Table 4. Selected physico-chemical properties of rice straw, rice husk, rice straw biochar, and rice husk biochar.

\begin{tabular}{|c|c|c|c|c|}
\hline Property & Rice Straw & Rice Husk & $\begin{array}{c}\text { Rice Straw } \\
\text { Biochar }\end{array}$ & $\begin{array}{c}\text { Rice Husk } \\
\text { Biochar }\end{array}$ \\
\hline $\mathrm{pH}$ (water) & 7.0 & 6.5 & 9.2 & 9.1 \\
\hline $\mathrm{CEC}\left(\mathrm{cmol} \mathrm{kg}^{-1}\right)$ & 38.0 & 34.5 & 75.6 & 66.6 \\
\hline Total nitrogen (\%) & 0.38 & 0.25 & 0.45 & 0.33 \\
\hline Available P (mg kg $\left.{ }^{-1}\right)$ & 10.7 & 9.8 & 14.3 & 14.3 \\
\hline Exchangeable $\mathrm{Ca}\left(\mathrm{mg} \mathrm{kg}^{-1}\right)$ & 3205 & 320 & 3599 & 1048 \\
\hline Exchangeable $\mathrm{Mg}\left(\mathrm{mg} \mathrm{kg}^{-1}\right)$ & 1288 & 2186 & 809 & 508 \\
\hline Exchangeable $\mathrm{K}\left(\mathrm{mg} \mathrm{kg}^{-1}\right)$ & 25,450 & 1945 & 12,030 & 4925 \\
\hline Exchangeable $\mathrm{Na}\left(\mathrm{mg} \mathrm{kg}^{-1}\right)$ & 52.1 & 59.3 & 246.3 & 256 \\
\hline
\end{tabular}

\subsection{Ammonia Loss Incubation Study}

The daily loss of $\mathrm{NH}_{3}$ from urea fertilizer during the period of the incubation study over 28 days is shown in Figure 3. There was no activity of $\mathrm{NH}_{3}$ volatilization in T0. Meanwhile, in (soil with urea only) $\mathrm{T} 1, \mathrm{NH}_{3}$ loss started on the second day after the application of urea. The $\mathrm{NH}_{3}$ volatilization started on third day in $\mathrm{T} 6$ and $\mathrm{T} 7$ (commercial biochar potting media). The loss sped up and peaked on fifth, eighth, and ninth days in $\mathrm{T} 1, \mathrm{~T} 6$, and $\mathrm{T} 7$, respectively. The $\mathrm{NH}_{3}$ loss in $\mathrm{T} 1, \mathrm{~T} 6$, and $\mathrm{T} 7$ started early, and similarly it ceased to $1 \%$ of added $\mathrm{N}$ early in the soil compared to the treatments amended with RSRH biochars (T2, T3, T4, and T5). In $\mathrm{T} 2$ and $\mathrm{T} 3$, the $\mathrm{NH}_{3}$ loss was delayed by up to 7 days while the loss of $\mathrm{NH}_{3}$ in $\mathrm{T} 4$ and $\mathrm{T} 5$ was delayed by up to 6 days. In T2 and T3, the loss peaked up on the fourteenth and fifteenth days, respectively; meanwhile, in T4 and T5, the loss peaked up on the twelfth day. The trend of the graph shows that the loss of $\mathrm{NH}_{3}$ peaked up and reduced gradually up to twenty-ninth day, until added urea ceased up to $1 \%$. The treatments with biochar as an additive (T2, T3, T4, and T5) significantly minimized $\mathrm{NH}_{3}$ loss compared to urea without additives (T1) and commercial biochar potting media (T6 and T7) (Table 5). Treatment $\mathrm{T} 3$ was more distinct in minimizing $\mathrm{NH}_{3}$ loss, which was about $41 \%$ followed by T2, T4, and T5 at 33\%, 30\%, and 27\%, respectively, over T1. Further, 
the $\mathrm{pH}$ of soil amended with RSRH biochars was significantly higher than that of T0, T1, T6, and T7.

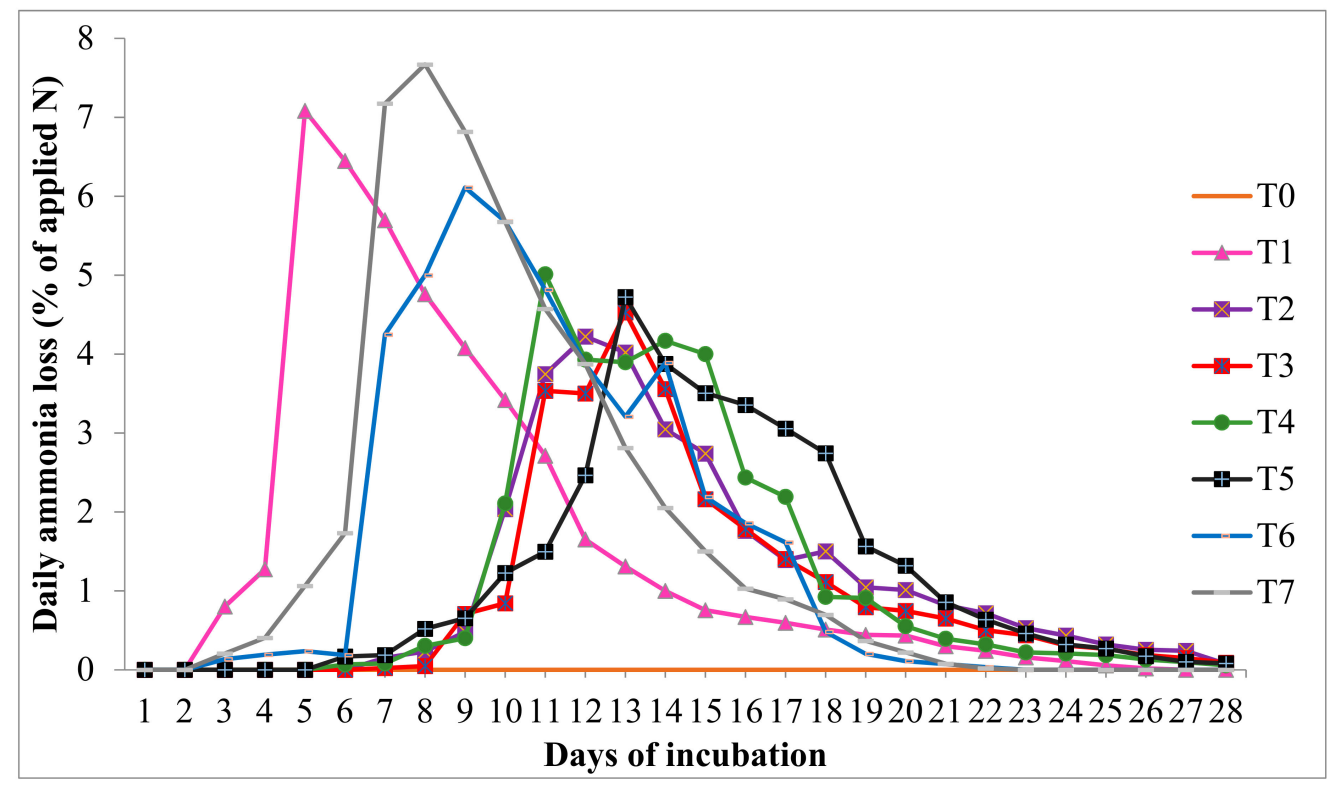

Figure 3. Ammonia volatilization over 28 days of incubation under waterlogged condition.

Table 5. Effect of treatments during ammonia volatilization study on soil $\mathrm{pH}$, exchangeable $\mathrm{NH}_{4}{ }^{+}$, exchangeable $\mathrm{NO}_{3}{ }^{-}$, and ammonia loss.

\begin{tabular}{|c|c|c|c|c|}
\hline Treatments & $\begin{array}{c}\mathrm{pH} \\
\text { (Water) }\end{array}$ & $\begin{array}{l}\mathrm{NH}_{4}^{+} \\
(\mathrm{ppm})\end{array}$ & $\begin{array}{l}\mathrm{NO}_{3}^{-} \\
(\mathrm{ppm})\end{array}$ & $\begin{array}{c}\text { Ammonia Loss } \\
(\%)\end{array}$ \\
\hline T0 & $5.53 \pm 0.06^{\mathrm{a}}$ & $106.67 \pm 12.01^{a}$ & $32.67 \pm 2.33^{\mathrm{ab}}$ & $0.00 \pm 0.00^{\mathrm{a}}$ \\
\hline $\mathrm{T} 1$ & $6.23 \pm 0.12^{b}$ & $256.67 \pm 29.63^{b}$ & $37.67 \pm 1.86^{a b}$ & $46.29 \pm 1.79$ de \\
\hline $\mathrm{T} 2$ & $8.06 \pm 0.06^{\mathrm{e}}$ & $500.1 \pm 2.06^{\mathrm{d}}$ & $56.30 \pm 4.33^{c}$ & $30.79 \pm 0.11 b c$ \\
\hline T3 & $7.95 \pm 0.02 \mathrm{de}$ & $458.5 \pm 17.96^{\mathrm{cd}}$ & $56.00 \pm 4.04^{\mathrm{c}}$ & $27.43 \pm 0.71^{\mathrm{b}}$ \\
\hline $\mathrm{T} 4$ & $7.88 \pm 0.02$ de & $394.67 \pm 6.12^{c}$ & $46.33 \pm 2.19^{b c}$ & $32.62 \pm 1.20^{\mathrm{c}}$ \\
\hline T5 & $7.75 \pm 0.03^{\mathrm{d}}$ & $289.33 \pm 6.17^{b}$ & $41.0 \pm 0.58^{a b c}$ & $33.66 \pm 0.50^{c}$ \\
\hline T6 & $7.38 \pm 0.03^{c}$ & $276.67 \pm 8.82^{b}$ & $30.33 \pm 4.98^{\mathrm{a}}$ & $44.13 \pm 0.16^{\mathrm{d}}$ \\
\hline $\mathrm{T} 7$ & $7.36 \pm 0.07^{\mathrm{c}}$ & $223.33 \pm 21.86^{b}$ & $30.34 \pm 2.33^{a}$ & $48.86 \pm 0.23^{\mathrm{e}}$ \\
\hline
\end{tabular}

Mean values within column with different letter(s) indicate significant difference between treatments by Tukey's test at $p \leq 0.05$. Columns represent the mean values $\pm \mathrm{SE}$.

Additionally, biochar successfully adsorbed nutrients from the soil. T2, T3, and T4 showed a significant $\mathrm{NH}_{4}{ }^{+}$retention in soil (Table 5) by retaining the highest amount of $\mathrm{NH}_{4}{ }^{+}$by $95 \%$ and $79 \%$, respectively, over $\mathrm{T} 1$, followed by $\mathrm{T} 4$ and $\mathrm{T} 5$, which were $54 \%$ and $12 \%$, respectively. Further, the $\mathrm{NO}_{3}{ }^{-}$ions in the soil were found to be higher in T2 and T3. Commercial biochar potting media T6 and T7 did not show any significant increment in retention of $\mathrm{NH}_{4}{ }^{+}$and $\mathrm{NO}_{3}{ }^{-}$in comparison to treatments amended with RSRH biochars.

\subsection{Soil Analysis in Pot Experiment}

Data for soil physical and chemical properties under different biochar treatments sampled after harvesting of rice plant at the heading stage (70 DAT) are presented in Tables 6-9. The total $\mathrm{N}$ in the soil was significantly higher in T2 and T3 compared with that in T0, T1, T4, and T5 (Table 6). However, there was no significant difference in soil total $\mathrm{N}$ among treatments amended with RSRH biochar (T2 and T3). Similarly, the results showed that there was no significant difference in the retention of $\mathrm{NH}_{4}{ }^{+}$and $\mathrm{NO}_{3}{ }^{-}$in between T2 and T3. Both treatments amended with RSRH biochar significantly increased the soil exchangeable $\mathrm{NH}_{4}{ }^{+}$and $\mathrm{NO}_{3}{ }^{-}$over the rest of the treatments. 
Table 6. Effects of rice straw and rice husk (RSRH) biochar on soil N, $\mathrm{NH}_{4}{ }^{+}$, and $\mathrm{NO}_{3}{ }^{-}$at harvest (70 days after transplantation (DAT)).

\begin{tabular}{cccc}
\hline Treatments & $\mathbf{N ~ ( \% )}$ & $\mathbf{N H}_{\mathbf{4}}{ }^{+}(\mathbf{p p m})$ & $\mathbf{N O}_{3}{ }^{-} \mathbf{( p p m )}$ \\
\hline T0 & $0.07 \pm 0.02^{\mathrm{a}}$ & $23.35 \pm 2.34^{\mathrm{a}}$ & $25.69 \pm 6.18^{\mathrm{a}}$ \\
T1 & $0.15 \pm 0.01^{\mathrm{b}}$ & $31.35 \pm 5.24^{\mathrm{a}}$ & $38.52 \pm 2.02^{\mathrm{ab}}$ \\
T2 & $0.21 \pm 0.07^{\mathrm{c}}$ & $122.59 \pm 2.02^{\mathrm{b}}$ & $97.07 \pm 3.21^{\mathrm{c}}$ \\
T3 & $0.18 \pm 0.08^{\mathrm{bc}}$ & $111.91 \pm 4.88^{\mathrm{b}}$ & $87.57 \pm 2.02^{\mathrm{c}}$ \\
T4 & $0.07 \pm 0.01^{\mathrm{a}}$ & $35.03 \pm 4.04^{\mathrm{a}}$ & $46.70 \pm 2.34^{\mathrm{b}}$ \\
T5 & $0.05 \pm 0.02^{\mathrm{a}}$ & $31.52 \pm 2.02^{\mathrm{a}}$ & $42.03 \pm 4.04^{\mathrm{ab}}$ \\
\hline
\end{tabular}

Mean values within column with different letter(s) indicate significant difference between treatments by Tukey's test at $p \leq 0.05$. Columns represent the mean values $\pm \mathrm{SE}$.

Table 7. Effects of RSRH biochar on soil pH, EC, total organic matter, and total C at harvest (70 DAT).

\begin{tabular}{|c|c|c|c|c|}
\hline Treatments & $\begin{array}{c}\mathrm{pH} \\
\text { (Water) }\end{array}$ & $\begin{array}{c}E C \\
\left(\mathrm{ds} \mathrm{m}^{-1}\right)\end{array}$ & $\begin{array}{c}\text { Total Organic } \\
\text { Matter (\%) }\end{array}$ & Total C \\
\hline T0 & $5.81 \pm 0.13^{a}$ & $0.006 \pm 0.001^{a}$ & $0.70 \pm 0.06^{a}$ & $0.41 \pm 0.03^{a}$ \\
\hline $\mathrm{T} 1$ & $6.17 \pm 0.03^{a}$ & $0.007 \pm 0.001^{\mathrm{a}}$ & $1.02 \pm 0.19^{\mathrm{a}}$ & $0.59 \pm 0.11^{\mathrm{a}}$ \\
\hline $\mathrm{T} 2$ & $7.50 \pm 1.27^{c}$ & $0.03 \pm 0.002 b c$ & $6.63 \pm 0.13^{c}$ & $2.10 \pm 0.08^{c}$ \\
\hline T3 & $7.41 \pm 0.31^{\mathrm{c}}$ & $0.04 \pm 0.006^{\mathrm{c}}$ & $6.57 \pm 0.24^{c}$ & $3.36 \pm 0.14^{\mathrm{c}}$ \\
\hline $\mathrm{T} 4$ & $6.83 \pm 0.06^{b c}$ & $0.02 \pm 0.001 \mathrm{abc}$ & $2.91 \pm 0.59^{b}$ & $1.69 \pm 0.34^{b}$ \\
\hline $\mathrm{T} 5$ & $6.67 \pm 0.07^{\mathrm{b}}$ & $0.01 \pm 0.001^{\mathrm{ab}}$ & $3.35 \pm 0.27^{b}$ & $1.94 \pm 0.16^{b}$ \\
\hline
\end{tabular}

Mean values within column with different letter(s) indicate significant difference between treatments by Tukey's test at $p \leq 0.05$. Columns represent the mean values $\pm \mathrm{SE}$.

Table 8. Effects of RSRH biochar on soil CEC, exchangeable acidity, exchangeable Al, and available $\mathrm{P}$ at harvest (70 DAT).

\begin{tabular}{ccccc}
\hline Treatments & CEC & $\begin{array}{c}\text { Exchangeable } \\
\text { Acidity } \\
\mathbf{( c m o l ~ k g ~}^{-1} \text { ) }\end{array}$ & $\begin{array}{c}\text { Exchangeable } \\
\text { Al }\end{array}$ & $\begin{array}{c}\text { Available } \mathbf{P} \\
\text { (ppm) }\end{array}$ \\
\hline T0 & $2.95 \pm 0.26^{\mathrm{a}}$ & $0.33 \pm 0.04^{\mathrm{b}}$ & $0.26 \pm 0.02^{\mathrm{a}}$ & $2.57 \pm 0.68^{\mathrm{a}}$ \\
T1 & $4.17 \pm 0.27^{\mathrm{ab}}$ & $0.32 \pm 0.03^{\mathrm{b}}$ & $0.31 \pm 0.03^{\mathrm{ab}}$ & $29.38 \pm 3.99^{\mathrm{b}}$ \\
T2 & $9.83 \pm 0.20^{\mathrm{c}}$ & $0.17 \pm 0.03^{\mathrm{a}}$ & $0.19 \pm 0.02^{\mathrm{ab}}$ & $115.35 \pm 3.03^{\mathrm{d}}$ \\
T3 & $9.60 \pm 0.32^{\mathrm{c}}$ & $0.18 \pm 0.01^{\mathrm{a}}$ & $0.14 \pm 0.01^{\mathrm{a}}$ & $110.90 \pm 5.60^{\mathrm{d}}$ \\
T4 & $4.47 \pm 0.26^{\mathrm{b}}$ & $0.32 \pm 0.01^{\mathrm{b}}$ & $0.35 \pm 0.02^{\mathrm{b}}$ & $51.37 \pm 0.97^{\mathrm{c}}$ \\
T5 & $3.80 \pm 0.21^{\mathrm{ab}}$ & $0.52 \pm 0.04^{\mathrm{c}}$ & $0.58 \pm 0.09^{\mathrm{c}}$ & $37.50 \pm 3.18^{\mathrm{bc}}$ \\
\hline
\end{tabular}

Mean values within column with different letter(s) indicate significant difference between treatments by Tukey's test at $p \leq 0.05$. Columns represent the mean values \pm SE.

Table 9. Effects of RSRH biochar on available $\mathrm{K}, \mathrm{Ca}, \mathrm{Mg}$, Zn, and Fe at harvest (70 DAT).

\begin{tabular}{|c|c|c|c|c|c|}
\hline Treatments & $\begin{array}{c}\text { Available K } \\
\left(\mathrm{mg} \mathrm{kg}^{-1}\right)\end{array}$ & $\begin{array}{c}\text { Available Ca } \\
\left(\mathrm{mg} \mathrm{kg}^{-1}\right)\end{array}$ & $\begin{array}{c}\text { Available Mg } \\
\left(\mathrm{mg} \mathrm{kg}^{-1}\right)\end{array}$ & $\begin{array}{l}\text { Available } \mathrm{Zn} \\
\left(\mathrm{mg} \mathrm{kg}^{-1}\right)\end{array}$ & $\underset{\left(\mathrm{mg} \mathrm{kg}^{-1}\right)}{\text { Available Fe }}$ \\
\hline T0 & $0.36 \pm 0.29^{a}$ & $0.43 \pm 0.02^{a b}$ & $0.08 \pm 0.002^{a}$ & $0.0020 \pm 0.0006^{\mathrm{a}}$ & $0.11 \pm 0.003^{\mathrm{ab}}$ \\
\hline $\mathrm{T} 1$ & $0.64 \pm 0.14^{\mathrm{a}}$ & $0.75 \pm 0.17^{\mathrm{b}}$ & $0.07 \pm 0.001^{\mathrm{a}}$ & $0.0023 \pm 0.0003^{\mathrm{a}}$ & $0.09 \pm 0.006^{\mathrm{a}}$ \\
\hline $\mathrm{T} 2$ & $0.89 \pm 0.12^{b}$ & $2.47 \pm 0.20^{c}$ & $0.04 \pm 0.003^{\mathrm{a}}$ & $0.0053 \pm 0.0003^{c}$ & $0.07 \pm 0.006^{\mathrm{a}}$ \\
\hline T3 & $1.25 \pm 0.07^{b}$ & $2.30 \pm 0.15^{c}$ & $0.05 \pm 0.002^{\mathrm{a}}$ & $0.0120 \pm 0.0017^{\mathrm{bc}}$ & $0.04 \pm 0.003^{\mathrm{a}}$ \\
\hline $\mathrm{T} 4$ & $0.25 \pm 0.05^{\mathrm{a}}$ & $0.10 \pm 0.01^{\mathrm{a}}$ & $0.04 \pm 0.001^{\mathrm{a}}$ & $0.0050 \pm 0.0001^{\mathrm{abc}}$ & $0.20 \pm 0.026^{\mathrm{b}}$ \\
\hline T5 & $0.29 \pm 0.03^{a}$ & $0.61 \pm 0.06^{a b}$ & $0.05 \pm 0.001^{\mathrm{a}}$ & $0.0047 \pm 0.0003^{\mathrm{ab}}$ & $0.35 \pm 0.043^{c}$ \\
\hline
\end{tabular}

Mean values within column with different letter(s) indicate significant difference between treatments by Tukey's test at $p \leq 0.05$. Columns represent the mean values $\pm \mathrm{SE}$.

The $\mathrm{pH}\left(\mathrm{H}_{2} \mathrm{O}\right)$ of the soil with organic amendments (RSRH biochar) $(\mathrm{T} 2, \mathrm{~T} 3$, $\mathrm{T} 4$, and T5) increased significantly compared with those without organic amendments (T0 and T1) (Table 7). The increase in the soil $\mathrm{pH}$ was consistent with that of the incubation study (Section 3.2). Soil EC was found to be significantly higher in treatments amended with RSRH biochar (T2 and T3) over T0 and T1. Further, T2 and T3 also showed a significant 
$(p<0.05)$ increment in total organic matter and total $\mathrm{C}$ compared to other treatments (Table 7). In addition, treatments with RSRH biochar (T2 and T3) also significantly increased the soil CEC compared to other treatments (Table 8).

The treatments with RSRH biochar (T2 and T3) significantly reduced the soil exchangeable acidity over T0, T1, T4, and T5 (Table 8). However, T2 and T3 did not reduced the soil exchangeable Al and Fe significantly in comparison to the soil alone (T0) and soil + urea (T1), but the RSRH-amended treatments reduced the soil exchangeable Al and Fe significantly compared to commercial biochar potting media (T4 and T5). Even though there was no significant reduction in Al and Fe in T2 and T3, nevertheless T2 and T3 had increased the soil available P significantly over the rest of the treatments (Table 8). Similar observations were observed in T2 and T3 for available K and Ca (Table 9). However, there was no significant difference in retention of available $\mathrm{Mg}$ and $\mathrm{Zn}$ in between all the treatments.

\subsection{Rice Plant Growth and Nutrient Uptake Influenced by Rice Straw and Rice Husk Biochar}

The rice plant dry weight, height, tiller number, panicle number, and greenness are summarized in Table 10. Treatments T2 and T3 showed a significant increase in plant dry weight, height, tiller number, panicle number, and greenness compared to other treatments. Similarly, the total N and available P contents in T2 and T3 were significantly higher than other treatments without biochar and treatments with potting media biochar (Table 11). Available K in T2 was recorded to be the highest among all the treatments. The concentrations of available $\mathrm{Ca}$ and $\mathrm{Mg}$ in treatments amended with RSRH biochar (T2 and T3) did not show any significant increase over T1.

Table 10. Effects of RSRH biochar on dry weight, height, tiller number, panicle number, and greenness at harvest (70 DAT).

\begin{tabular}{cccccc}
\hline Treatments & Dry Weight $(\mathbf{g})$ & Height $(\mathbf{c m})$ & Tiller Number & Panicle Number (\%) & Greenness (\%) \\
\hline T0 & $7.64 \pm 0.84^{\mathrm{a}}$ & $41.94 \pm 0.19^{\mathrm{a}}$ & $2.00 \pm 0.33^{\mathrm{a}}$ & $1.00 \pm 0.02^{\mathrm{a}}$ & $100.00 \pm 0.97^{\mathrm{a}}$ \\
T1 & $22.97 \pm 2.9^{\mathrm{c}}$ & $76.18 \pm 2.92^{\mathrm{b}}$ & $3.00 \pm 0.33^{\mathrm{a}}$ & $2.00 \pm 0.33^{\mathrm{a}}$ & $106.31 \pm 3.47^{\mathrm{ab}}$ \\
T2 & $39.17 \pm 1.58^{\mathrm{d}}$ & $101.57 \pm 1.95^{\mathrm{c}}$ & $8.00 \pm 0.88^{\mathrm{b}}$ & $8.00 \pm 0.88^{\mathrm{b}}$ & $158.11 \pm 3.88^{\mathrm{d}}$ \\
T3 & $38.57 \pm 0.97^{\mathrm{d}}$ & $96.83 \pm 1.84^{\mathrm{c}}$ & $9.00 \pm 0.89^{\mathrm{b}}$ & $7.00 \pm 0.89^{\mathrm{b}}$ & $154.39 \pm 6.20^{\mathrm{d}}$ \\
T4 & $17.54 \pm 1.14^{\mathrm{bc}}$ & $73.20 \pm 3.07^{\mathrm{b}}$ & $3.00 \pm 0.33^{\mathrm{a}}$ & $3.00 \pm 0.34^{\mathrm{a}}$ & $125.23 \pm 2.84^{\mathrm{c}}$ \\
T5 & $14.62 \pm 1.37^{\mathrm{ab}}$ & $67.67 \pm 0.98^{\mathrm{b}}$ & $2.00 \pm 0.34^{\mathrm{a}}$ & $1.00 \pm 0.33^{\mathrm{a}}$ & $123.31 \pm 3.58^{\mathrm{bc}}$
\end{tabular}

Mean values within column with different letter(s) indicate significant difference between treatments by Tukey's test at $p \leq 0.05$. Columns represent the mean values $\pm \mathrm{SE}$.

Table 11. Effects of RSRH biochar on N, P, K, Ca, and Mg concentrations at harvest (70 DAT).

\begin{tabular}{|c|c|c|c|c|c|}
\hline Treatments & $\begin{array}{c}\mathrm{N} \\
(\%)\end{array}$ & $\begin{array}{c}P \\
\left(\mathrm{mg} \mathrm{kg}^{-1}\right)\end{array}$ & $\begin{array}{c}\mathrm{K} \\
\left(\mathrm{mg} \mathrm{kg}^{-1}\right)\end{array}$ & $\begin{array}{c}\mathrm{Ca} \\
\left(\mathrm{mg} \mathrm{kg}^{-1}\right)\end{array}$ & $\begin{array}{c}\mathrm{Mg} \\
\left(\mathrm{mg} \mathrm{kg}^{-1}\right)\end{array}$ \\
\hline T0 & $0.31 \pm 0.02^{\mathrm{a}}$ & $3.87 \pm 0.35^{\mathrm{a}}$ & $3380 \pm 3.47^{a}$ & $1616.7 \pm 4.44^{\mathrm{a}}$ & $780 \pm 2.04^{a}$ \\
\hline $\mathrm{T} 1$ & $0.89 \pm 0.07^{b}$ & $6.77 \pm 0.49^{a}$ & $2239.2 \pm 1.27^{b c}$ & $3100 \pm 1.73^{b c d}$ & $1260 \pm 1.29 \mathrm{ab}$ \\
\hline $\mathrm{T} 2$ & $1.48 \pm 0.02^{\mathrm{c}}$ & $44.00 \pm 1.55^{\mathrm{e}}$ & $3276 \pm 3.38^{d}$ & $4675 \pm 4.33^{\mathrm{d}}$ & $2000 \pm 2.85^{b}$ \\
\hline T3 & $1.41 \pm 0.04^{\mathrm{c}}$ & $39.85 \pm 0.03^{d}$ & $2860 \pm 2.83^{\mathrm{cd}}$ & $3768 \pm 2.40^{\mathrm{cd}}$ & $1275 \pm 2.98^{a b}$ \\
\hline $\mathrm{T} 4$ & $0.90 \pm 0.03^{b}$ & $18.43 \pm 0.55^{c}$ & $1849 \pm 1.26^{b}$ & $3050 \pm 2.02^{b c}$ & $1220 \pm 1.64^{a b}$ \\
\hline $\mathrm{T} 5$ & $0.80 \pm 0.15^{b}$ & $12.53 \pm 0.72^{b}$ & $1593 \pm 1.38^{b}$ & $2200 \pm 4.53^{\mathrm{ab}}$ & $1090 \pm 1.93^{\mathrm{a}}$ \\
\hline
\end{tabular}

Mean values within column with different letter(s) indicate significant difference between treatments by Tukey's test at $p \leq 0.05$. Columns represent the mean values $\pm \mathrm{SE}$.

The rice plant $\mathrm{N}$ uptake in treatment amended with $\mathrm{RSRH}$ biochar at $5-10 \mathrm{t} \mathrm{ha}^{-1}$ (T2 and T3) was significantly higher than other treatments (Figure 4). Further, in T2 and T3, the plant $\mathrm{P}$ and $\mathrm{K}$ uptake showed a significant increase in comparison to T0, T1, T4, and T5 (Figures 5 and 6). Treatment T2 and T3 significantly increased total Ca uptake of rice plant compared to other treatments (Figure 7). The total $\mathrm{Mg}$ uptake was significantly higher in T2 compared to other treatments (Figure 8). Further, the treatments with RSRH biochars (T2 and T3) significantly improved nutrient use efficiency in rice plant compared with T1 (Table 12). 


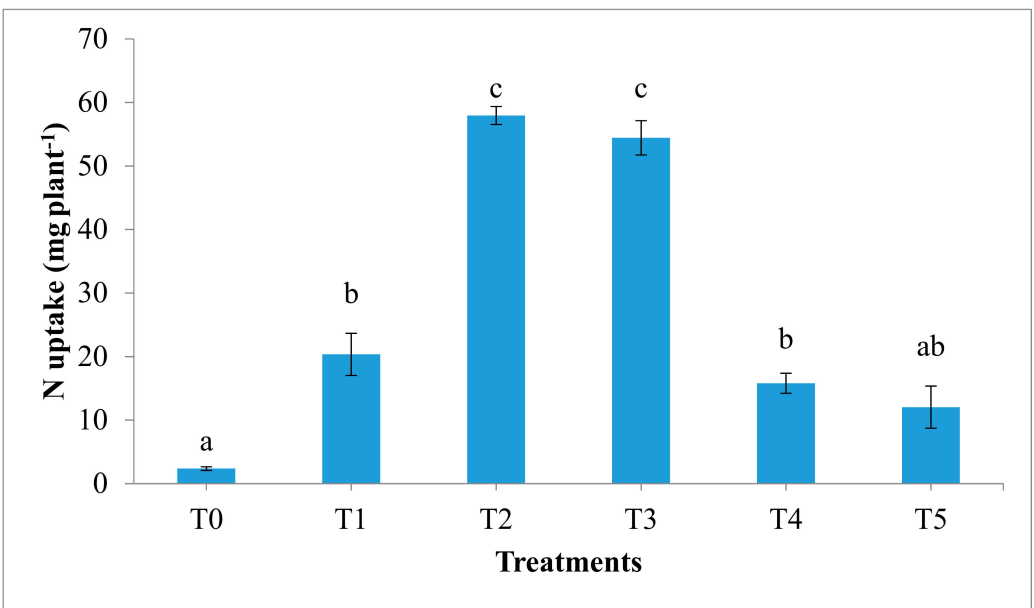

Figure 4. Effects of treatments on total $\mathrm{N}$ uptake at harvest (70 DAT). Mean values with different letter(s) indicate significant difference between treatments by Tukey's test at $p \leq 0.05$. Bars represent the mean values $\pm \mathrm{SE}$.

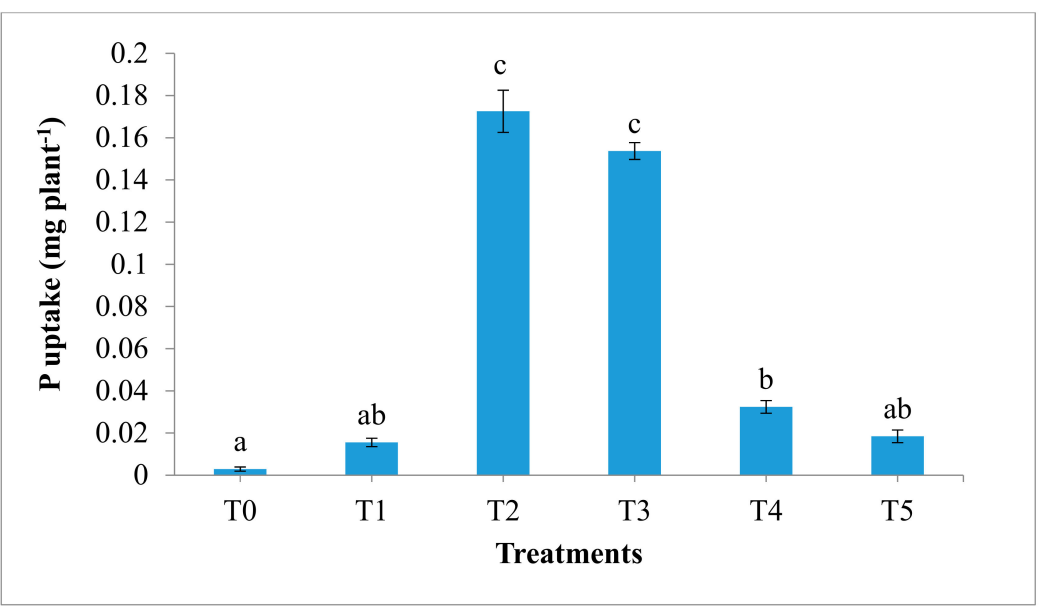

Figure 5. Effects of treatments on available P uptake at harvest (70 DAT). Mean values with different letter(s) indicate significant difference between treatments by Tukey's test at $p \leq 0.05$. Bars represent the mean values $\pm \mathrm{SE}$.

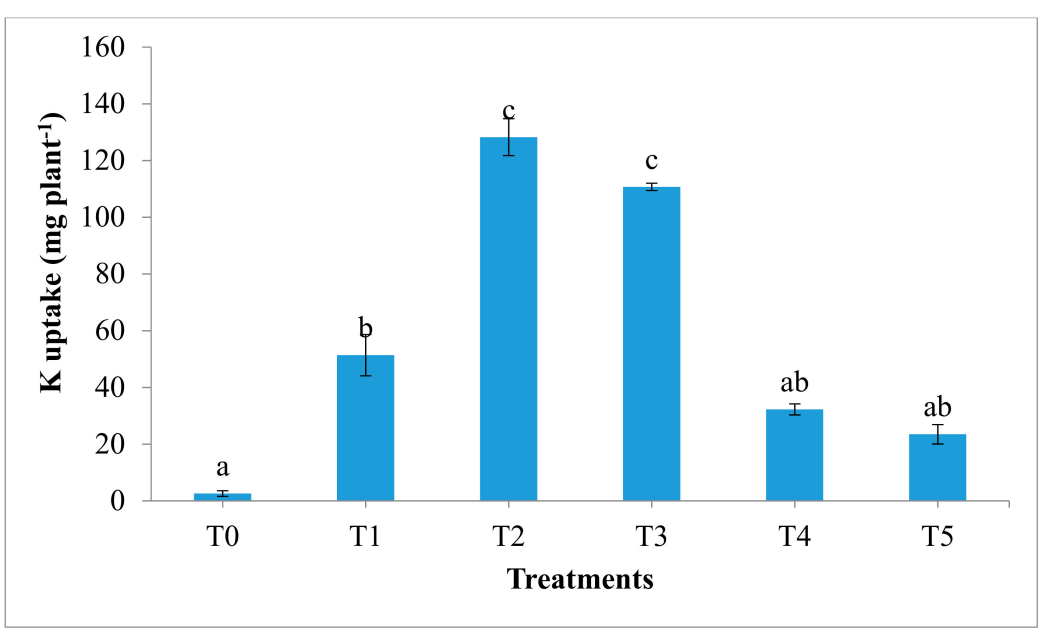

Figure 6. Effects of treatments on total K uptake at harvest (70 DAT). Mean values with different letter(s) indicate significant difference between treatments by Tukey's test at $p \leq 0.05$. Bars represent the mean values $\pm \mathrm{SE}$. 


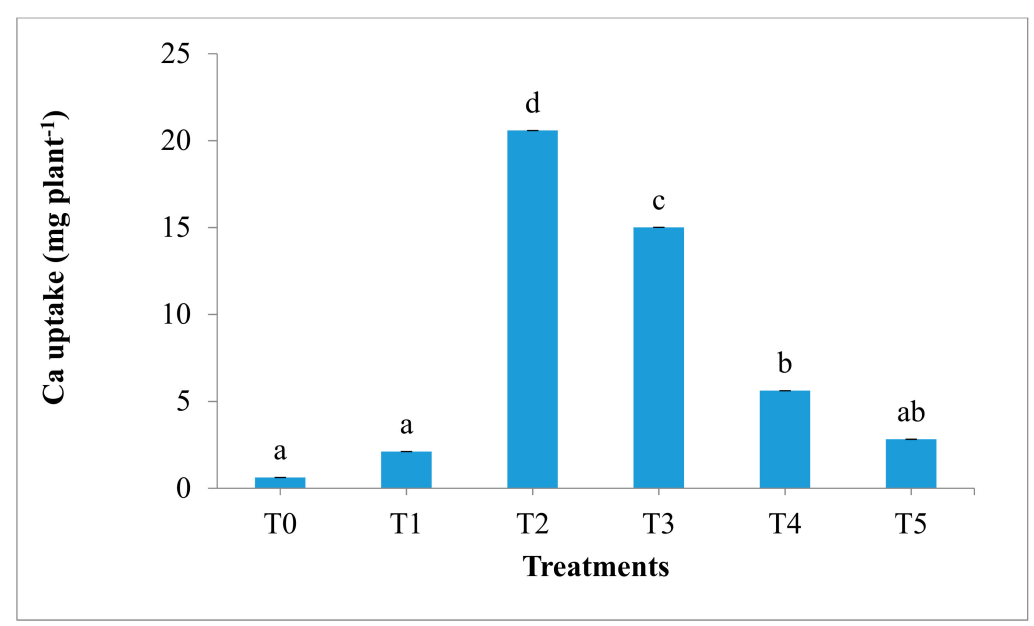

Figure 7. Effects of treatments on total Ca uptake at harvest (70 DAT). Mean values with different letter(s) indicate significant difference between treatments by Tukey's test at $p \leq 0.05$. Bars represent the mean values $\pm \mathrm{SE}$.

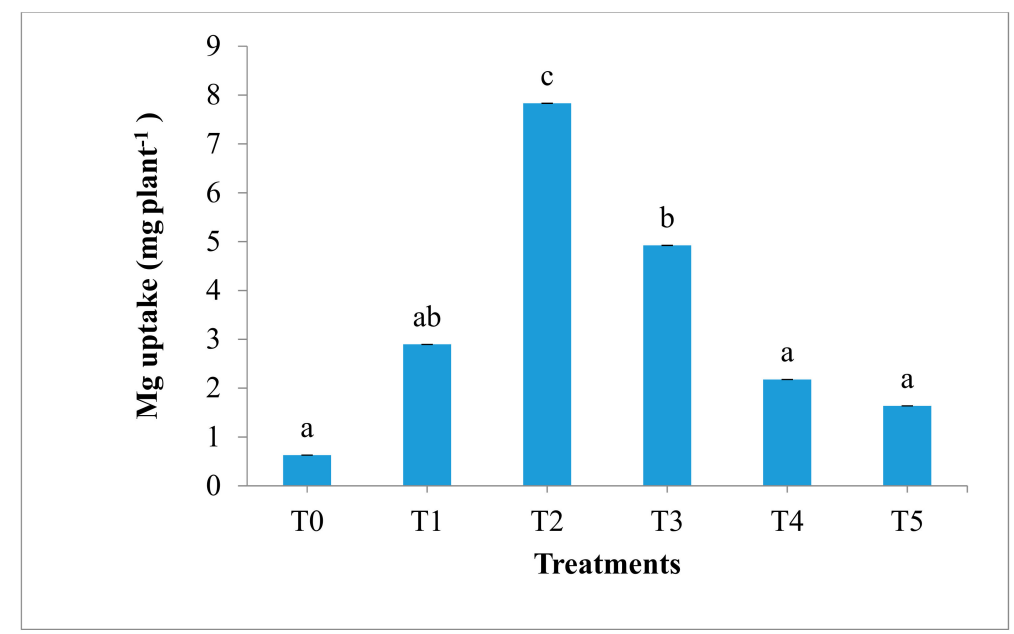

Figure 8. Effects of treatments on total Mg uptake at harvest (70 DAT). Mean values with different letter(s) indicate significant difference between treatments by Tukey's test at $p \leq 0.05$. Bars represent the mean values \pm SE.

Table 12. Effects of RSRH biochar on N, P, and K use efficiency at harvest (70 DAT).

\begin{tabular}{cccc}
\hline Treatments & N Use Efficiency & P Use Efficiency & K Use Efficiency \\
\hline T1 & $15.17 \pm 1.36^{\mathrm{a}}$ & $0.013 \pm 0.002^{\mathrm{a}}$ & $8.52 \pm 3.89^{\mathrm{a}}$ \\
T2 & $56.59 \pm 1.26^{\mathrm{b}}$ & $0.17 \pm 0.013^{\mathrm{b}}$ & $97.07 \pm 3.43^{\mathrm{b}}$ \\
T3 & $53.08 \pm 2.82^{\mathrm{b}}$ & $0.15 \pm 0.004^{\mathrm{b}}$ & $87.57 \pm 1.32^{\mathrm{b}}$ \\
T4 & $14.45 \pm 1.65^{\mathrm{a}}$ & $0.03 \pm 0.003^{\mathrm{a}}$ & $46.70 \pm 1.61^{\mathrm{a}}$ \\
T5 & $10.68 \pm 3.19^{\mathrm{a}}$ & $0.02 \pm 0.002^{\mathrm{a}}$ & $42.03 \pm 3.60^{\mathrm{a}}$ \\
\hline
\end{tabular}

Mean values within column with different letter(s) indicate significant difference between treatments by Tukey's test at $p \leq 0.05$. Columns represent the mean values $\pm \mathrm{SE}$.

\section{Discussion}

\subsection{Ammonia Volatilization Study}

The RSRH-amended biochars successfully minimized $\mathrm{NH}_{3}$ volatilization by delaying by up to 6-7 days. The total loss of $\mathrm{NH}_{3}$ in $\mathrm{RSRH}$ amended treatments was significantly low compared to the treatments without biochar and treatments with biochar potting media. The ability to minimize $\mathrm{NH}_{3}$ lies in the nature of biochar. Biochars' porosity and 
larger surface area increase the adsorption rate of $\mathrm{NH}_{4}{ }^{+}$and $\mathrm{NO}_{3}{ }^{-}$ions and reduce the volatilization of $\mathrm{NH}_{3}$ [35]. The dual characteristics of biochar enhanced the adsorption of both negatively and positively charged ions onto its exchange sites [36]. This was further supported by the findings in this study where the treatments amended with RSRH biochar, specifically 5 and $10 \mathrm{tha}^{-1}$, retained more $\mathrm{NH}_{4}{ }^{+}$and $\mathrm{NO}_{3}{ }^{-}$ions in the soil (Table 5). The increased $\mathrm{NH}_{4}{ }^{+}$and $\mathrm{NO}_{3}{ }^{-}$ions in the soil might be related to the CEC of RSRH biochar which is $>66.6 \mathrm{cmol}_{\mathrm{c}} \mathrm{kg}^{-1}$ (Table 4). The higher retention of nutrients might also be due to biochar that degrade very late and, as a result, the adsorbed nutrients being released slowly. Sinclair et al. [37] reported that biochar in soil is very resilient and breaks down only sparingly over the long term; thus, captured nutrients are released slowly. In addition, biochar has significant carbonaceous components due to incomplete combustion of various organic components; hence, biochar remains in the soil long term $[38,39]$. The presence of biochar for a long period of time in the soil, and the slow release process of the adsorbed nutrients increases the nutrients in the soil for plant uptake. The characteristic of RSRH biochar acting as a slow release fertilizer means it is able to minimize $\mathrm{NH}_{3}$ loss and benefit the plant.

Moreover, biochar-amended treatments increased the soil $\mathrm{pH}$. The $\mathrm{pH}$ of the soil amended with RSRH biochar (T2-T5) was significantly higher than the rest of the treatments. The soil $\mathrm{pH}$ increased during the period of the $\mathrm{NH}_{3}$ volatilization study may have been due to the inherent properties of biochar, which is alkaline in nature ( $>9)$ (Table 4). Previously, it was reported that $\mathrm{NH}_{3}$ volatilization is rapid in alkaline soils [40]. However, the results in this study showed lesser $\mathrm{NH}_{3}$ volatilization even though the soil was near neutral. This may have been due to the increased adsorption and conversion to $\mathrm{NH}_{4}{ }^{+}$and $\mathrm{NO}_{3}{ }^{-}$over $\mathrm{NH}_{3}$. Additionally, Kelly [41] stated that the $\mathrm{pH}$ increase in soil amended with biochar was not high enough to enhance $\mathrm{NH}_{3}$ volatilization. Since there were no organic amendments in the $\mathrm{T} 0$ and $\mathrm{T} 1$, the soil remained acidic.

\subsection{Soil Nutrients Improvement}

The higher retention of soil total $\mathrm{N}$, exchangeable $\mathrm{NH}_{4}{ }^{+}$, and $\mathrm{NO}_{3}{ }^{-}$were possible because of the high CEC of RS (75.6) and RH ( $\left.66.6 \mathrm{cmol} \mathrm{kg}^{-1}\right)$ biochar (Table 4). Further, the use of biochar as an organic amendment increased the retention of $\mathrm{N}$ due to the deceleration of $\mathrm{N}$ mineralization. This was possible due to the high organic matter of biochar. This was in agreement with Latifah et al. [42] and $\mathrm{He}$ et al. [43]. Moreover, the higher soil total $\mathrm{N}$, exchangeable $\mathrm{NH}_{4}{ }^{+}$and $\mathrm{NO}_{3}{ }^{-}$in T2 and T3 suggests that the use of RSRH biochar was effective in reducing $\mathrm{N}, \mathrm{NH}_{4}{ }^{+}$, and $\mathrm{NO}_{3}{ }^{-}$loss in soils, which is consistent with the findings by Wang et al. [44]. Nitrogen ion retention by RSRH biochar is due to its nature of having numerous pores and a larger surface area which adsorbs $\mathrm{NH}_{4}{ }^{+}$and $\mathrm{NO}_{3}{ }^{-}$onto its surface (Figures 1 and 2). Zhang et al. [45] stated that biochar has a special porous structure and surface functional group that adsorbs nutrient ions effectively. In addition, the ions' adsorption capacity of biochar has been proven in a study conducted by Chen et al. [35]. The amorphous crystalline structure with numerous cracks on the surface area of biochar creates a large volume of empty pores that can be filled with nutrients [46]. The cracks lead to the formation of micro and macro pores during the heating time and the cracks formed are too numerous to be sealed off. This increases the porosity of biochar, where the porosity aids the adsorption capacity of the biochar. Additionally, the biochar has dual adsorption capacity where it adheres both negative and positive charged ions on its surface [47]. This strengthens the reasoning underlying the capacity of biochar to retain more $\mathrm{N}, \mathrm{NH}_{4}{ }^{+}$, and $\mathrm{NO}_{3}{ }^{-}$in soil.

The presence of biochar regardless of RSRH biochar or commercial biochar increases the $\mathrm{pH}$ of the soil. The increase in soil $\mathrm{pH}$ was because of the rapid proton $\left(\mathrm{H}^{+}\right)$exchange between soil and organic amendments (biochar) [48,49]. Further, the increase in soil $\mathrm{pH}$ was also correlated with the further decomposition of biochar, where it enhanced the formation of organic anions, which consumed the protons available in the soil and solubilized the inherent $\mathrm{K}, \mathrm{Ca}, \mathrm{Mg}$, and $\mathrm{Na}$ contents of biochar. Eventually, this increased the soil $\mathrm{pH}$ 
which was amended with biochars. This was in agreements to Ch'ng et al. [50] who stated that soil $\mathrm{pH}$ increases with the addition of organic amendments. Increase in the soil $\mathrm{pH}$ under T1 could be due to the dissolution of $\mathrm{Ca}$ and $\mathrm{Mg}$ contained in CIRP.

Further, reduction of soil exchangeable acidity in treatments amended with RSRH biochar was partly related to the increase in soil $\mathrm{pH}$. It has been reported by previous researchers that soil $\mathrm{pH}$ increases as the exchangeable $\mathrm{Al}$ decreases [51,52]. This is due to the precipitation of exchangeable and soluble Fe as insoluble $\mathrm{Al}$ and Fe hydroxides [53]. However, this is in contrast with the findings of this study, whereby the increase in soil $\mathrm{pH}$ was not affected by the presence of exchangeable $\mathrm{Al}$ and Fe. Despite the highest level of the exchangeable $\mathrm{Al}$ and $\mathrm{Fe}$ in $\mathrm{T} 4$ and $\mathrm{T} 5$, the soil $\mathrm{pH}$ was increased significantly. This might be due to the alkaline nature of the biochars. Biochars are alkaline due to their ash content which releases base cations; hence, biochar addition neutralizes soil acidity [54]. Biochars have abundant soluble and exchangeable basic cations $\left(\mathrm{Ca}^{2+}, \mathrm{Mg}^{2+}, \mathrm{K}^{+}\right.$, and $\left.\mathrm{Na}^{+}\right)$ which can be released into the acid soil easily. This suggests that the presence of biochar increases soil $\mathrm{pH}$ and reduces exchangeable acidity, although biochar does not significantly reduce the exchangeable $\mathrm{Al}$ and $\mathrm{Fe}$.

The application of biochar increases the availability of soil organic matter. This finding is consistent with that of Lehman et al. [55]. The RSRH biochar increased the soil organic matter significantly, which might be due to slow mineralization and degradation by microbes. This was supported by studies of Bruun et al. [56] and Lehmann et al. [57] who stated that low mineralization rates of biochar underlines the biochar stability and its inherent ability to resist microbial degradation. Bruun and El-Tehery [58] further concluded that decreasing rates of soil organic matter mineralization may be caused by different factors including aeration and $\mathrm{N}$ availability. Application of RSRH biochar increased the soil organic $C$. The biochar role as a $C$ storage in the soil was further confirmed by Lehmann et al. [55] and Demisie et al. [59]. Biochar is a C rich substrate and resistant to decomposition due to its aromatic structure [60]. The RSRH biochar interacts synergistically with soil to enhance the soil organic matter and soil C. Treatments amended with RSRH biochar also increased the soil EC. Higher soluble salt presence in the biochars might have resulted in the higher EC values. Chintala et al. [61] stated that biochar increases soil EC because cations on biochar surface may not bind strongly by electrostatic force, causing it to dissolve as a soluble salt. Gundale and Deluca [62] and Chan et al. [63] further agree that incorporation of biochar to acidic soil increases soil EC due to the release of weakly bound cations and anions into soil solution which are available for plant uptake.

Soil amended with RSRH biochar increased the soil CEC (Table 8). This could be due to the inherent characteristic of biochar which has a high surface area and porous nature [64]. The increase of soil CEC amended with RSRH biochar may also be due to the slow oxidation of biochar material as a result of biotic and abiotic factors which oxygenate the biochar surface functional group and boost the development of organo-mineral complexes [65-67]. Liang et al. [68] also stated that the charge density of per unit biochar surface was high, so its incorporation could increase the cations' sorption of soils.

In the presence of biochar, soil available $\mathrm{P}$ increased significantly, and this could be attributed to the addition of biochar, which binds $\mathrm{PO}_{4}{ }^{3-}$ ions. The presence of polar and non-polar surface sites on biochar enabled it to adsorb more nutrients [36]. It was further agreed by Nelson et al. [69] and Sarkhot et al. [70] that biochar adsorbed both $\mathrm{NH}_{4}{ }^{+}, \mathrm{NO}_{3}{ }^{-}$, and $\mathrm{PO}_{4}{ }^{3-}$ onto its exchange sites. The adsorbed $\mathrm{PO}_{4}{ }^{3-}$ onto the biochar surface reduced the $\mathrm{P}$ fixation to $\mathrm{Al}$ and Fe. Fixation of $\mathrm{P}$ with $\mathrm{Al}$ and $\mathrm{Fe}$ formed insoluble oxides and hydroxides, causing it to become unavailable for plant uptake. However, application of RSRH biochar into the soil successfully adsorbed P. Ch'ng et al. [71] stated that organic amendments (compost and biochar) successfully reduced soil P fixation by $\mathrm{Al}$ and Fe.

Incorporation of RSRH biochar increased available $\mathrm{K}$ and available Ca significantly (Table 9). The increase might be due to the inherent contents of these cations in the treatments amended with RSRH biochar. The increase of available K and available Ca can be associated with higher CEC of RSRH biochar (Table 4). Lehmann et al. [72] reported that 
the addition of biochar improved CEC of the soil, thus directly increasing the retention of basic cations in soil. Further, the highest retention of available cations ( $\mathrm{K}$ and $\mathrm{Ca}$ ) might be attributed to the presence of ash in biochar which helps in the immediate release of Ca and $\mathrm{K}[64,73,74]$.

\subsection{Rice Plant Growth, Nutrient Uptake, and Nutrient Efficiency}

The rice plant height, tiller number, panicle number, and greenness in the treatments amended with RSRH biochar were significantly higher than in the rest of the treatments. This finding suggests a positive effect of biochar addition on the growth of rice plants. The plant growth increased with the application of RSRH biochar. This was due to the improvement of soil chemical properties such as increased availability of plant nutrients $(\mathrm{N}, \mathrm{P}$, and $\mathrm{K}$ ) and a decrease of soil acidity. The availability of $\mathrm{N}, \mathrm{P}$, and $\mathrm{K}$ was readily available in soil for efficient plant uptake. Improved rice plant physical growth directly increased the dry weight of the plants under RSRH biochar treatments.

In terms of rice plant $\mathrm{N}$ uptake, $\mathrm{T} 3$ (10 tha ${ }^{-1} \mathrm{RSRH}$ biochar) significantly improved the $\mathrm{N}$ concentration and uptake, and this indicated the reason for less $\mathrm{N}$ loss from the soil-plant system. Similarly, the N use efficiency was the highest in T3 compared to other treatments (Table 12). This was because the soil-biochar mixture might have encouraged the formation of $\mathrm{NH}_{4}{ }^{+}$and $\mathrm{NO}_{3}{ }^{-}$over $\mathrm{NH}_{3}$. Ahmed et al. [29] reported similar observations. Omar et al. [75] also stated that the plant $\mathrm{N}$ uptake and use efficiency could be related with the ability of organic amendments to reduce $\mathrm{NH}_{3}$ volatilization. Further, the adsorbed $\mathrm{N}$, $\mathrm{NH}_{4}{ }^{+}$, and $\mathrm{NO}_{3}{ }^{-}$in biochar exchange sites were being released slowly into the soil such that it met the demand of rice plant growth stages. It was proven that biochar can be an excellent alternative source for a slow release agent of nutrients [76]. However, there was no significant difference in $\mathrm{N}$ uptake between T1, T2, T4, and T5. This might be due to the lesser biochar application rate in T2, where the capability to adsorb nutrients was lesser and almost equal to non-biochar-amended treatments (T1). Further, lesser adsorption capability may have led to minor urea volatilization and denitrification. This may have been the cause of lesser $\mathrm{N}$ uptake and use efficiency in T1, T2, T4, and T5.

The $\mathrm{P}, \mathrm{K}$, and $\mathrm{Ca}$ concentrations, uptake, and use efficiency of rice plant in $\mathrm{T} 2$ and T3 were significantly higher compared to other treatments. Addition of RSRH biochar increased the soil $\mathrm{pH}$ and adsorption of $\mathrm{PO}_{4}{ }^{3-}$ onto its exchange sites by reducing fixation by $\mathrm{Al}$ and $\mathrm{Fe}$. The $\mathrm{PO}_{4}{ }^{3-}$ ions ere not released immediately and this favored absorption by the plant root system. This could have improved better root growth in the rice plants which received biochar amendments (T2 and T3), thus increasing P, K, Ca, and Mg uptake in rice plants. Similarly, the plant nutrient use efficiency increased in line with plant nutrient uptake.

\section{Conclusions}

Incorporation of RSRH biochar effectively minimized $\mathrm{NH}_{3}$ loss from being volatilized. Biochar at an application rate of 5 and $10 \mathrm{tha}^{-1}$ successfully adsorbed $\mathrm{NH}_{4}{ }^{+}$and $\mathrm{NO}_{3}{ }^{-}$, and released them slowly for efficient rice plant uptake. It also improved soil organic matter, C, CEC, soil available P, and available K, and reduced soil exchangeable acidity. RSRH biochar also improved plant nutrient uptake and dry matter production of rice plants. The increase in rice plant nutrient uptake and use efficiency increased in line with the increase of readily available soil nutrients. Hence, RSRH biochar has a big potential to minimize $\mathrm{N}$ loss and retain more nutrients for efficient plant uptake.

Author Contributions: Conceptualization, G.S.; methodology, G.S.; investigation, G.S.; writingoriginal draft preparation, G.S.; editing, H.Y.C., N.M.Z., P.S., S.N.H.M.A.; supervision, H.Y.C.; project administration, H.Y.C.; funding acquisition, H.Y.C., P.S. All authors have read and agreed to the published version of the manuscript. 
Funding: This research was funded by Malaysia Fundamental Research Grant Scheme (Grant No.: R/FRGS/A0700/01459A/002/2018/00563), UMK-MOF Social Enterprise Program (Grant No.: R/MOF/A07.00/01397A/007/2020/00721), and TUMKEI-MPC Student Entrepreneur. The APC will be funded by Malaysia Fundamental Research Grant Scheme (Grant No.: R/FRGS/A0700/01459A/ 002/2018/00563), UMK-MOF Social Enterprise Program (Grant No.: R/MOF/A07.00/01397A/007/ 2020/00721), TUMKEI-MPC Student Entrepreneur, and the University Malaysia Kelantan Deputy Vice Chancellor's (Research and Innovation) Office.

Acknowledgments: The authors would like to thank the Malaysia Ministry of Education, Malaysia Ministry of Finance, and University Malaysai Kelantan Entrepreneurship Institute for financial assistance and University Malaysia Kelantan Jeli Campus for providing research facilities.

Conflicts of Interest: The authors declare no conflict of interests.

\section{References}

1. Sariam. Aerob Rice, a Key to Malaysia's Food Security. 2014. Available online: https://blogmardi.files.wordpress.com/2014/... / scientia-mardi-vol-001-march-2014.pdf (accessed on 19 February 2018).

2. Xu, M.; Li, D.; Li, J.; Qin, D.; Hosen, Y.; Shen, H.; Cong, R.; He, X. Polyolefin-coated urea decreases ammonia volatilization in a double rice system of southern China. Agron. J. 2013, 105, 277-284. [CrossRef]

3. Liu, T.; Huang, J.; Chai, K.; Cao, C.; Li, C. Effects of $\mathrm{N}$ fertilizer sources and tillage practices on $\mathrm{NH}_{3}$ volatilization, grain yield, and $\mathrm{N}$ use efficiency of rice fields in Central China. Front. Plant Sci. 2018, 9, 385. [CrossRef]

4. Zhang, W.F.; Zhang, F.S. Research Report of Chinese Fertilizer Development; China Agricultural University Press: Beijing, China, 2013; pp. 90-93.

5. Mariano, E.; de Sant Ana Filho, C.R.; Bortoletto-Santos, R.; Bendassolli, J.A.; Trivelin, P.C. Ammonia losses following surface application of enhanced-efficiency nitrogen fertilizers and urea. Atmos. Environ. 2019, 203, 242-251. [CrossRef]

6. Jadon, P.; Selladurai, R.; Yadav, S.S.; Coumar, M.V.; Dotaniya, M.L.; Singh, A.K.; Bhadouriya, J.; Kundu, S. Volatilization and leaching losses of nitrogen from different coated urea fertilizers. J. Soil Sci. Plant Nutr. 2018, 18, 1036-1047. [CrossRef]

7. Zheng, J.; Mmari, W.N.; Funakawa, S. Ammonia volatilization following urea application at maize fields in the East African highlands with different soil properties. Biol. Fertil. Soils 2018, 54, 411-422. [CrossRef]

8. Sarkar, N.; Ghosh, S.K.; Bannerjee, S.; Aikat, K. Bioethanol production from agricultural wastes: An overview. Renew. Energy 2012, 37, 19-27. [CrossRef]

9. Rehman, H.A.; Razzaq, R. Benefits of biochar on the agriculture and environment-a review. Int. J. Environ. Anal. Chem. 2017, 4, 1-3. [CrossRef]

10. Lehmann, J.; Joseph, S. Biochar for environmental management: An introduction. In Biochar for Environmental Management 2015; Routledge: London, UK, 2009; pp. 33-46.

11. Yeboah, E.; Ofori, P.; Quansah, G.W.; Dugan, E.; Sohi, S.P. Improving soil productivity through biochar amendments to soils. Afr. J. Environ. Sci. Technol. 2009, 3, 34-41.

12. Yang, K.; Zhu, L.; Yang, J.; Lin, D. Adsorption and correlations of selected aromatic compounds on a KOH-activated carbon with large surface area. Sci. Total Environ. 2018, 618, 1677-1684. [CrossRef]

13. Aghoghovwia, M.P.; Hardie, A.G.; Rozanov, A.B. Characterisation, adsorption and desorption of ammonium and nitrate of biochar derived from different feedstocks. Environ. Technol. 2020, 1-14. [CrossRef]

14. Abdel-Fattah, T.M.; Mahmoud, M.E.; Ahmed, S.B.; Huff, M.D.; Lee, J.W.; Kumar, S. Biochar from woody biomass for removing metal contaminants and carbon sequestration. J. Ind. Eng. Chem. 2015, 22, 103-109. [CrossRef]

15. Koyama, S.; Katagiri, T.; Minamikawa, K.; Kato, M.; Hayashi, H. Effects of rice husk charcoal application on rice yield, methane emission, and soil carbon sequestration in andosol paddy soil. Jpn. Agric. Res. Qual. 2016, 50, 319-327. [CrossRef]

16. Mohammadi, A.; Cowie, A.; Mai, T.L.A.; de la Rosa, R.A.; Kristiansen, P.; Brandao, M.; Joseph, S. Biochar use for climate-change mitigation in rice cropping systems. J. Clean. Prod. 2016, 116, 61-70. [CrossRef]

17. Peech, H.M. Hydrogen-ion activity. In Methods of Soil Analysis, Part 2; Black, C.A., Evans, D.D., Ensminger, L.E., White, J.L., Clark, F.E., Dinauer, R.C., Eds.; American Society of Agronomy: Madison, WI, USA, 1965; p. 64.

18. Tan, K.H. Soil Sampling, Preparation, and Analysis, 2nd ed.; CRC Press: Boca Raton, FL, USA, 2005; p. 672.

19. Bremner, J.M. Total nitrogen. In Methods of Soil Analysis, Part 2; Black, C.A., Evans, D.D., Ensminger, L.E., White, J.L., Clark, F.F., Dinauer, R.C., Eds.; American Society of Agronomy: Madison, WI, USA, 1965; pp. 1149-1178.

20. Mehlich, A. Determination of $\mathrm{P}, \mathrm{Ca}, \mathrm{Mg}, \mathrm{K}, \mathrm{Na}$ and $\mathrm{NH}_{4}$; North Carolina State University Soil Test Division: Raleigh, NC, USA, 1953; p. 145.

21. Murphy, J.; Riley, J.P. A modified single solution method for the determination of phosphate in natural waters. Anal. Chim. Acta 1962, 27, 31-36. [CrossRef]

22. Cottenie, A. Soil testing and plant testing as a basis of fertilizer recommendation. FAO Soils Bull. 1980, 38, 70-73.

23. Rowell, D.L. Soil Science, Methods and Applications; Longman Group UK Limited: London, UK, $1994 ;$ pp. 86-87.

24. Keeney, D.R.; Nelson, D.W. Nitrogen-inorganic forms. In Methods of Soil Analysis, Part 2, 2nd ed.; Page, A.G., Keeney, D.R., Baker, D.E., Miller, R.H., Rhoades, J.D., Eds.; American Society of Agronomy: Madison, WI, USA, 1982; pp. 643-698. 
25. Sakhiya, A.K.; Anand, A.; Kaushal, P. Production, activation, and applications of biochar in recent times. Biochar 2020, 2, $253-285$. [CrossRef]

26. Siva, K.B.; Aminuddin, H.; Husni, M.H.A.; Manas, A.R. Ammonia volatilization from urea as affected by tropical-based palm oil mill effluent (Pome) and peat. Commun. Soil Sci. Plan. Anal. 1999, 30, 785-804. [CrossRef]

27. Ahmed, O.H.; Aminuddin, H.; Husni, M.H.A. Effects of urea, humic acid and phosphate interactions in fertilizer microsites on ammonia volatilization and soil ammonium and nitrate contents. Int. J. Agric. Res. 2006, 1, 25-31. [CrossRef]

28. Ahmed, O.H.; Aminuddin, H.; Husni, M.H.A. Reducing ammonia loss from urea and improving soil-exchangeable ammonium retention through mixing triple superphosphate, humic acid and zeolite. Soil Use Manag. 2006, 22, 315-319. [CrossRef]

29. Ahmed, O.H.; Husin, A.; Hanif, A.H.M. Ammonia volatilization and ammonium accumulation from urea mixed with zeolite and triple superphosphate. Acta Agric. Scand. Sect. B Soil Plant Sci. 2008, 58, 182-186.

30. Bozorgi, H.R.; Faraji, A.; Danesh, R.K. Effect of plant density on yield and yield components of rice. Appl. Sci. 2011, $12,2053-2057$.

31. Muda Agricultural Development Authority. Rice Check; Muda Agricultural Development Authority: Kedah, Malaysia, 2014.

32. Palanivell, P.; Ahmed, O.H.; Majid, A.N.M. Minimizing ammonia volatilization from urea, improving lowland rice (cv. MR219) seed germination, plant growth variables, nutrient uptake, and nutrient recovery using clinoptilolite zeolite. Arch. Agron. Soil Sci. 2016, 62, 708-724. [CrossRef]

33. Lija, M.; Ahmed, O.H.; Susilawati, K. Maize (Zea mays L.) nutrient use efficiency as affected by formulated fertilizer with Clinoptilolite Zeolite. Emir. J. Food Agric. 2014, 26, 284-292. [CrossRef]

34. Dobermann, A.R. Nitrogen Use Efficiency-State of the Art. Agron. Hortic. Fac. Publ. 2005, 316.

35. Chen, C.R.; Phillips, I.R.; Condron, L.M.; Goloran, J.; Xu, Z.H.; Chan, K.Y. Impacts of greenwaste biochar on ammonia volatilisation from bauxite processing residue sand. Plant Soil. 2013, 367, 301-312. [CrossRef]

36. Laird, D.A.; Fleming, P.; Davis, D.D.; Horto, R.; Wang, B.; Karlen, D.L. Impact of biochar amendments on the quality of a typical Midwestern agricultural soil. Geoderma 2010, 158, 443-449. [CrossRef]

37. Sinclair, K.; Slavich, P.; Van Zwieten, L.; Downie, A. Productivity and nutrient availability on a Ferrosol: Biochar, lime and fertiliser. In Proceedings of the Australian Society of Agronomy Conference, Adelaide, Australia, 21-25 September 2008; pp. 21-25.

38. Sohi, S.P.; Krull, E.; Lopez-Capel, E.; Bol, R. A review of biochar and its use and function in soil. In Advances in Agronomy; Academic Press: Cambridge, UK, 2010; pp. 47-82.

39. Novak, J.M.; Busscher, W.J.; Laird, D.L.; Ahmedna, M.; Watts, D.W.; Niandou, M.A. Impact of biochar amendment on fertility of a southeastern coastal plain soil. Soil Sci. 2009, 174, 105-112. [CrossRef]

40. Schomberg, H.H.; Gaskin, J.W.; Harris, K.; Das, K.C.; Novak, J.M.; Busscher, W.J.; Watts, D.W.; Woodroof, R.H.; Lima, I.M.; Ahmedna, M.; et al. Influence of biochar on nitrogen fractions in a coastal plain soil. J. Environ. Qual. 2012, 41, 1087-1095. [CrossRef]

41. Kelly, C.N.; Calderón, F.C.; Acosta-Martínez, V.; Mikha, M.M.; Benjamin, J.; Rutherford, D.W.; Rostad, C.E. Switchgrass biochar effects on plant biomass and microbial dynamics in two soils from different regions. Pedosphere 2015, 25, 329-342. [CrossRef]

42. Latifah, O.; Ahmed, O.H.; Majid, N.M.A. Improving ammonium and nitrate release from urea using clinoptilolite zeolite and compost. Sci. World J. 2015, 2015, 574201.

43. He, Z.L.; Alva, A.K.; Calvert, D.V.; Banks, D.J. Ammonia volatilization from different nitrogen fertilizers and effects of temperature and soil pH. Soil Sci. 1999, 164, 750-758. [CrossRef]

44. Wang, Z.; Guo, H.; Shen, F.; Yang, G.; Zhang, Y.; Zeng, Y.; Deng, S. Biochar produced from oak sawdust by Lanthanum (La)involved pyrolysis for adsorption of ammonium $\left(\mathrm{NH}_{4}{ }^{+}\right)$, nitrate $\left(\mathrm{NO}_{3}{ }^{-}\right)$, and phosphate $\left(\mathrm{PO}_{4}{ }^{3-}\right)$. Chemosphere 2015, 119, 646-653. [CrossRef] [PubMed]

45. Zhang, J.; Zhang, Z.; Shen, G.; Wang, R.; Gao, L.; Kong, F.; Zhang, J. Growth performance, nutrient absorption of tobacco and soil fertility after straw biochar application. Int. J. Agric. Biol. 2016, 18. [CrossRef]

46. Brown, R.A.; Kercher, A.K.; Nguyen, T.H.; Nagle, D.C.; Ball, W.P. Production and characterization of synthetic wood chars for use as surrogates for natural sorbents. Org. Geochem. 2006, 37, 321-333. [CrossRef]

47. Waters, D.; Condon, J.; Van Zwieten, L.; Moroni, S. Biochar-ion interactions: An investigation of biochar charge and its effect on ion retention. In Proceedings of the 19th World Congress of Soil Science, Brisbane, Australia, 1-6 August 2010.

48. Tang, C.; Sparling, G.P.; McLay, C.D.A.; Raphael, C. Effect of short-term legume residue decomposition on soil acidity. Soil Res. 1999, 237, 561-573.

49. Wong, M.T.F.; Nortcliff, S.; Swift, R.S. Method for determining the acid ameliorating capacity of plant residue compost, urban waste compost, farmyard manure, and peat applied to tropical soils. Commun. Soil Sci. Plant 1998, 29, 2927-2937. [CrossRef]

50. Ch'ng, H.Y.; Ahmed, O.H.; Ab Majid, N.M. Improving phosphorus availability, nutrient uptake and dry matter production of Zea mays L. on a tropical acid soil using poultry manure biochar and pineapple leaves compost. Exp. Agric. 2016, 52, 447. [CrossRef]

51. Narambuye, F.X.; Haynes, R.J. Effect of organic amendments on soil $\mathrm{pH}$ and Al solubility and use of laboratory indices to predict their liming effect. Soil Sci. 2006, 171, 754-763. [CrossRef]

52. Opala, P.A.; Okalebo, J.R.; Othieno, C.O. Effects of organic and inorganic materials on soil acidity and phosphorus availability in a soil incubation study. ISRN Agron. 2012, 2012, 597216. [CrossRef]

53. Zeng, Q.; Liao, B.; Jiang, Z.; Zhou, X.; Tang, C.; Zhong, N. Short-term changes of pH value and Al activity in acid soils after urea fertilization. Chin. J. Appl. Ecol. 2005, 16, 249-252. 
54. Obia, A.; Cornelissen, G.; Mulder, J.; Dörsch, P. Effect of soil pH increase by biochar on NO, $\mathrm{N}_{2} \mathrm{O}$ and $\mathrm{N}_{2}$ production during denitrification in acid soils. PLOS ONE 2015, 10, e0138781. [CrossRef] [PubMed]

55. Lehmann, J.; Gaunt, J.; Rondon, M. Bio-char sequestration in terrestrial ecosystems-A review. Mitig. Adapt. Strateg. Glob. Chang. 2006, 11, 395-419. [CrossRef]

56. Bruun, S.; Jensen, E.S.; Jensen, L.S. Microbial mineralization and assimilation of black carbon: Dependency on degree of thermal alteration. Org. Geochem. 2008, 39, 839-845. [CrossRef]

57. Lehmann, J.; Joseph, S. (Eds.) Biochar for environmental management: An introduction. In Biochar for Environmental ManagementScience and Technology; Earthscan Publisher: London, UK, 2009; pp. 1-9.

58. Bruun, S.; EL-Zehery, T. Biochar effect on the mineralization of soil organic matter. Pesqui. Agropecu Bras. 2012, 47, 665-671. [CrossRef]

59. Demisie, W.; Liu, Z.; Zhang, M. Effect of biochar on carbon fractions and enzyme activity of red soil. Catena 2014, 121, 214-221. [CrossRef]

60. Kuzyakov, Y.; Bogomolova, I.; Glaser, B. Biochar stability in soil: Decomposition during eight years and transformation as assessed by compound-specific 14C analysis. Soil Biol. Biochem. 2014, 70, 229-236. [CrossRef]

61. Chintala, R.; Mollinedo, J.; Schumacher, T.E.; Malo, D.D.; Julson, J.L. Effect of biochar on chemical properties of acidic soil. Arch. Agron. Soil Sci. 2014, 60, 393-404. [CrossRef]

62. Gundale, M.J.; DeLuca, T.H. Charcoal effects on soil solution chemistry and growth of Koeleria macrantha in the Ponderosa Pine/Douglas-fir ecosystem. Biol. Fertil. Soils 2007, 43, 303-311. [CrossRef]

63. Chan, K.Y.; Van Zwieten, L.; Meszaros, I.; Downie, A.; Joseph, S. Using poultry litter biochars as soil amendments. Soil Res. 2008, 46, 437-444. [CrossRef]

64. Nigussie, A.; Kissi, E.; Misganaw, M.; Ambaw, G. Effect of biochar application on soil properties and nutrient uptake of lettuces (Lactuca sativa) grown in chromium polluted soils. Am. Eurasian J. Agric. Environ. Sci. 2012, 12, 369-376.

65. Ma, Y.J.; Li, S.G.; Wang, Z.Q. Effect of weathered coal on the colloidal property of soils. Tu Jang Hsueh Pao 1979, 16, 22-28. (In Japanese)

66. Glaser, B. Eigenschaften und Stabilität des Humuskörpers der Indianerschwarzerden Amazoniens. In Bayreuther Bodenkundliche Berichte; Institute of Soil Science and Soil Geography, University of Bayreuth: Bayreuth, Germany, 1999; Volume 68.

67. Glaser, B.; Haumaier, L.; Guggenberger, G.; Zech, W. The Terra Preta phenomenon-A model for sustainable agriculture in the humid tropics. Naturwissenschaften 2001, 88, 37-41. [CrossRef] [PubMed]

68. Liang, B.L.; Solomon, J.; Kinyangi, D.; Grossman, J.; O’Neill, J.; Skjemstad, B.; Thies, J.O.; Petersen, F.J.; Neves, J. Black carbon increases cation exchange capacity in soils. Soil Sci. Soc. Am. J. 2006, 70, 1719-1730. [CrossRef]

69. Nelson, N.O.; Agudelo, S.C.; Yuan, W.Q.; Gan, J. Nitrogen and phosphorus availability in biochar-amended soils. Soil Sci. 2011, 176, 218-226. [CrossRef]

70. Sarkhot, D.V.; Berhe, A.A.; Ghezzehei, T.A. Impact of biochar enriched with dairy manure effluent on carbon and nitrogen dynamics. J. Environ. Qual. 2012, 41, 1107-1114. [CrossRef]

71. Ch'ng, H.Y.; Ahmed, O.H.; Majid, N.M.A.; Jalloh, M.B. Reducing soil phosphorus fixation to improve yield of maize on a tropical acid soil using compost and biochar derived from agro-industrial wastes. Compost Sci. Util. 2017, 25, 82-94. [CrossRef]

72. Lehmann, J.; Rilig, M.C.; Thies, J.; Masiello, C.A.; Hockaday, W.C.; Crowley, D. Biochar affects on soil biota-A review. Soil Biol. Biochem. 2011, 43, 1812-1836. [CrossRef]

73. Scheuner, E.T.; Makeschin, F.; Wells, E.D.; Carter, P.Q. Short-term impacts of harvesting and burning disturbances on physical and chemical characteristics of forest soils in western Newfoundland, Canada. Eur. J. Forest Res. 2004, 123, 321-330. [CrossRef]

74. Niemeyer, T.; Niemeyer, M.; Mohamed, A.; Fottner, S.; Härdtle, W. Impact of prescribed burning on the nutrient balance of Heath Lands with particular reference to nitrogen and phosphorus. Appl. Veg. Sci. 2005, 8, 183-192. [CrossRef]

75. Omar, L.; Ahmed, O.H.; Majid, N.M.A. Enhancing nutrient use efficiency of maize (Zea mays L.) from mixing urea with zeolite and peat soil water. Int. J. Phys. Sci. 2011, 6, 3330-3335.

76. Liu, X.; Liao, J.; Song, H.; Yang, Y.; Guan, C.; Zhang, Z. A biochar-based route for environmentally friendly controlled release of nitrogen: Urea-loaded biochar and bentonite composite. Sci. Rep. 2019, 9, 1-12. [CrossRef] [PubMed] 